\title{
Liste chronologique des intendants de l'hôpital Manșūrī au temps des sultans mamelouks (684-923/1285-1517)
}

\author{
Rania Ossama Ali Fikri \\ Guide touristique, Faculte des Lettres, Universite de Ain Chams
}

\begin{tabular}{|c|c|}
\hline ARTICLE INFO & ABSTRACT \\
\hline $\begin{array}{l}\text { Keywords: } \\
\text { Le māristān } \\
\text { (bimāristān); } \\
\text { l'hôpital Manșūrī; } \\
\text { l'intendant de } \\
\text { l'hôpital Manșūrī; } \\
\text { l'époque mamelouke. } \\
\text { (JÄAUTH) } \\
\text { Vol. 20, No. 2, } \\
\text { (2021), } \\
\text { PP.1-43. }\end{array}$ & $\begin{array}{l}\text { L'époque des sultans mamelouks avait connu beaucoup de } \\
\text { fonctions religieuses, administratives et militaires. Parmi les } \\
\text { fonctions religieuses, il y avait l'intendance de l'hôpital } \\
\text { Manșūrī classifiée comme telle par al-Qalqašandī et qui } \\
\text { n'avait pas de siège à la séance du sultan. Son intendance fut } \\
\text { souvent confiée aux plus notables émirs parmi les gens du } \\
\text { sabre en Égypte. Ce poste occupe le neuvième rang parmi } \\
\text { les intendants des fonctions religieuses. L'hôpital Manșūrī } \\
\text { est un des plus célèbres hôpitaux fondés à l'époque } \\
\text { mamelouke. Son renom fut très retentissant en Égypte ainsi } \\
\text { qu'à l'étranger. Il avait joui des soins des sultans mamelouks } \\
\text { ainsi que de leurs émirs. Malgré son importance, cette } \\
\text { fonction ne fut pas l'objet d'une étude méticuleuse qui se } \\
\text { pencherait minitieusement sur ses titulaires. Cette recherche } \\
\text { vise ainsi à jeter la lumière sur ce poste si noble d'après les } \\
\text { informations disponibles. Cette étude a, par ailleurs, abouti à } \\
\text { des résultats fructueux dont le plus important est la liste } \\
\text { chronologique des titulaires de ce poste dès son } \\
\text { établissement jusqu'à la chute de l'époque mamelouke. Les } \\
\text { biographies et les sources mameloukes nous ont permis de } \\
\text { rendre compte de l'effectif réel des titulaires de ce poste } \\
\text { ainsi que de la durée d'occupation de chaque intendant pour } \\
\text { pouvoir juger de la stabilité ce cette charge. Cette recherche } \\
\text { se termina, somme toute, par une étude analytique afin de } \\
\text { découvrir les raisons de la décadence de ce noble poste. }\end{array}$ \\
\hline
\end{tabular}

\section{Introduction}

L'hôpital (māristān $)^{1}$ Manșūrī $^{2}$ est considéré comme le plus célèbre parmi les hôpitaux édifiés à l'époque mamelouke. Il avait acquis une grande notoriété en

\footnotetext{
1. Les deux termes maristān et bimaristān sont synonymes mais la première appelation est plus fréquement citée dans les sources mameloukes. Ce terme est dérivé d'un mot persan qui signifie le domicile du faible (baīt al-ḍa îff). Muhī al-Dīn ibn 'Abd al-Ẓāhir, Tašrīf al-aīyām wa'l-'ușūr fi sirat almalik al-Manșūr, réalisé par Murād Kāmil et révisé par Muḥammad 'Alī al-Nağğār, Le Caire, 1961, 55, $n^{\circ}$ 5; Șārim al-Dīn Ibrāhīm ibn Muhammad ibn Aydumur al-'Alā’î connu par Ibn Duqmāq, al-Nafḥa almiskīya fìl-dawla al-turkīya, réalisé par 'Umr 'Abd al-Salām Tadmurī, 1 ère éd, Beyrouth, 1992, 79, $\mathrm{n}^{\circ}$ 7; Šams al-Dīn Muḥammad al-Saḥmāwī, al-Ṭağr al-bāsim fĩ șināat al-kātib wa'l-kātim, réalisé par Ašraf Muḥammad Anas, Le Caire, 2009, vol. I, 412. Il y avait deux genres de bimāristān: fixe et mobile celui qui se déplace derrière les épidémies ainsi que les guerres connu actuellement par ambulance. Notons que I’hôpital Manșūrī n'était pas le premier lieu de soins médicaux en Égypte musulmane. Ibn
} 
Égypte ainsi qu'à l'étranger. Les sultans mamelouks et leurs émirs lui avaient accordé beaucoup de soins. Le célèbre voyageur Ibn Baṭuṭa l'avait signalé en disant, "Quant à l'hôpital Manșūrī, situé entre les deux palais près du tombeau du sultan al-Malik al-Manșūr Qalāwūn, est absolument indiscriptible de par les meubles et les médicaments dont il est équipé et qui sont, tout à fait, intestimables. On raconte que ses dépenses avaient atteint mille dinars par jour $»^{3}$. Ledit māristān fut bâti par le sultan al-Manșūr Qalāwūn en 683/1283 ${ }^{4}$ et les travaux de construction avaient duré onze mois et quelques jours ${ }^{5}$. Il avait confié cette tâche ${ }^{6}$ à l'émir 'Alam al-Dīn Sanğar al-Šuğà $\overline{1}^{7}$. Le sultan s'était désigné, par ailleurs, l'intendance de l'hôpital durant sa

Ṭūlūn, al-Īhš̌ĩd et Saladin en avaient fondées. Doris Abou Seif, Sylvie Denoix et J.C Garcin, "Le Caire», extrait de «Grandes villes méditterranéennes du monde musulman, Paris, 2000, 194-195.

2- D'après le nom du sultan al-Manșūr Qalāwūn al-Alfī (678-689/1279-1290) qui avait acheté la salle de Sit al-Mulk, la fille du calife fatimide al-'Azīz bī Allah connue plus tard sous le nom de la maison de l'émir Faḩr al-Dīn Ğaharkas puis la maison de Misk et finalement par la maison al-Quțbīya appartenant à l'émir Quțb al-Dīn Aḥmad, le fils d'al-Malik al-'Ādil Abī Bakr ibn Ayyūb. Elle sera sous la possession de ses héritiers jusqu'à sa prise par le sultan alManșūr Qalāwūn de Hātūn, la fille d'al-Malik al-'Ādil, en échange du palais de l'émeraude le 18 rabī'l 682/16 juin 1283. Le sultan al-Manșūr Qalāwūn avait ordonné de bâtir sur son emplacement un complexe architectural (hôpital, coupole et collège). Les travaux de construction furent achevés en rabī II 683/juin 1284. Le sultan s'est dirigé vers l'hôpital en compagnie des émirs, des juges et des savants et il a bu un gobelet de boisson en disant "j'ai consacré ce groupe à mes similaires et mes inférieurs, au maître et au mamelouk, soldat et émir, au grand et petit, au libre et à l'esclave, aux mâles et aux femelles». II avait consacré beaucoup de ses possessions telles que les caravansérails, les boutiques, les bains publics, les hôtels et des provinces en Syrie dont le revenu de ses biens-morts atteignit une somme considérable par mois et il consacra un grand part de cette somme à l'honneur de I'hôpital. Ibn 'Abd al-Ẓāhir, Tašrīf, 56, 127; Šihāb al-Dīn Aḥmad ibn 'Abd al-Wahāb al-Nuwairī, Nihāyat al-arab fí funūn al-adab, réalisé par Nağīb et Hiš̌mat Fawāz, Beyrouth, 2004, vol. XXXI, 70; Abī al-'Abbās Aḥmad al-Qalqašandī, Șubḥ al-a'ša fi șinā'at al-inšā, Le Caire, 1918, vol. III, 369-370; Taqī al-Dīn Abū'l-'Abbās Aḥmad ibn 'Alī 'Abd al-Qādir al-Maqrizī, al-Sulūk li ma rifat dūwal al-mulūk, Beyrouth, 1997, vol. II, 175-177; al-Ḥasan ibn Umar ibn Habīib, Taḍkirat al-nabih fĩ ayyām al-Manșūr wa banīh, réalisé par Muhammad Muhammad Amīn, Le Caire, 1976, vol. I, 301; Muḥammad Muhammad Amīn; al-Awqāf wa'l-hayā al-iğtimā ìya fí Mișr (648-923/1250-1517), Le Caire, 1980, 126; 'T̄mād Badr al-Dīn Abū Gāzī, Mulāḥaẓāt 'ala ihtișașāt al-'āmilīn fī baīt al-māl wa musamayātihim fĩ 'așr al-Mamālīk al-Ğarākissa, Annales Islamologiques, vol. XXXIII, 1999, 33.

3. Ibn Ḥabīb, Taḍkirat, vol. I, 300; Muḥammad ibn 'Abdallah ibn Bațūța, Riḥlat ibn Bațūța nommé

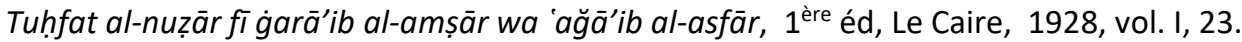

4- Al-Maqrīzī, al-Sulūk, vol. II, 186.

5- Rukn al-Dīn ibn 'Abdallah Baibars al-Manșūrī, al-Tuhfa al-mulūkīya fíl-dawla al-turkīya, réalisé par 'Abd al-Ḥamīd Șāliḥ Ḥimdān, 1 ère éd, Le Caire, 1987, 111; ibn Ḥabīb, Taḍkirat, vol. I, 30.

Ibn Duqmāq avait mentionné que les travaux de construction avaient duré dix mois. Al-Ğawhar alțamin fì sair al-ḩulafā' wa'l-mulūk wa'l-salāțīn, réalisé par Sa'īd 'Abd al-Fattāḥ 'Āšūr, L'Arabie Saoudite, 1982, 299; al-Nafha, 79.

6- Baibars al-Manșūrī, al-Tuhfa, 111; al-Qalqašandī, Șubḥ, vol. III, 369-370; al-Maqrīzī, al-Sulūk, vol. II, 175.

7- L'émir 'Alam al-Dīn Sanğar al-Šuğā'ì était le vizir et le vice-sultan à Damas tué en 693/1294. AlȘuqā'ī, Tālī kitāả wafĩyāt al-'a'īyān, réalisé par Jacqueline Sublet, Damas, 1974, 90-91, nº 132; Șalāḥ al-

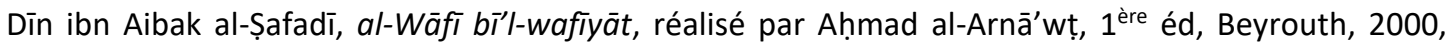
vol. XV, 289-290, n 5216; Ibn Ḥabīb, Taḍkirat, vol. I, 172; Ğamāl al-Dīn Abū'-I-Mahāsin Yūsuf ibn 
vie puis elle sera attribuée à ses fils et finalement au chef des musulmans chafiites ${ }^{8}$. La gestion de l'hôpital fut confiée aux vizirs et leurs analogues ${ }^{9}$. Dès lors, la prise en charge du māristān était devenue une des plus nobles et des plus sublimes fonctions à l'époque mamelouke. Elle occupa une position prestigieuse parmi les fonctions religieuses connues sous les Mameloukes ${ }^{10}$.

Al-Qalqašandī l'avait classifiée comme une des fonctions religieuses dont le titulaire n'avait pas de siège à la séance sultanienne. Son intendance fut communément confiée aux plus notables émirs d'Égypte parmi les gens d'épée ${ }^{11}$. Al-Saḥmāwī, qui a vécu au cours du IX/XV siècle, la classa neuvième parmi les postes des intendants des fonctions religieuses ${ }^{12}$. Quant aux titulaires de ce poste, ibn Tag̉rībirdī et Ibn Iyās avaient mentionné que celui-ci fut souvent confié au maréchal (atābik al-'askar)de ${ }^{13}$ l'Égypte ${ }^{14}$. Ibn Iyās avait ajouté, pour sa part, que l'intendance du māristān était une fonction très importante dans l'État confiée au maréchal qui, après avoir revêtu une robe d'honneur (hil'at istiqrār) ${ }^{15}$ se dirigeait vers l'hôpital dans un majestueux cortège $^{16}$. Cette fonction avait également connu un habit de perpétuation (hil'at alistimrār) si le titulaire continue à remplir les tâches de ce poste ${ }^{17}$.

Tagrībirdī, al-Manhal al-șāfĩ wa'l-mustawfi ba'd al-wāfi, réalisé par Muḥammad Muḥammad Amīn, Le Caire, 1990, vol. VI, 80-83, n 1117; al-Dalīl al-šāfi 'ala al-manhal al-șāfi, réalisé par Muhammad Fahīm Šaltūt, Le Caire, 1998, vol. I, 325, n 1114.

8- Ibn 'Abd al-Z̄āhir, Tašrīf, 55-56.

9-Al-Qalqašandī, Șubḥ, vol. III, 370.

10. Ġars al-Dīn Halīl Ibn Šāhin al-Ẓāhirī, Zubdat kašf al-mamālik wa bayān al-turuq wa'l-masālik, réalisé par Bulus Rawis, Paris, 1894, 115; al-Qalqašandī, Șubh, vol. IV, 38.

11. Al-Qalqašandī, Șubḥ, vol. IV, 38.

12- Al-Saḥmāwī, al-Taǵr, vol. I, 412.

13 - Le maréchal (atābik al-'askar) est un terme d'origine turque qui se compose de de deux syllabes: $a t ̦ a ̄$ qui signifie père et bik qui signifie émir alors ațābik signifie le père des émirs, ou le plus grand émir après le vice- sultan. On peut lui confier la régence d’un sultan mineur. Al-Qalqašandī et d'autres historiens indiquent que le chef de l'armée n'avait pas une fonction selon un ordre mais, c'était surtout un titre de glorification. Al-Qalqašandī, Șubh, vol. IV, 18; ibn Šāhīn al-Z̄āhirī, Zubdat, 112-113; ibn Taġrībirdī, al-Nuğūm al-zāhira fĩ mulūk Mișr wa'l-Qāhira, Le Caire, 1963, vol. VII, 184, $\mathrm{n}^{\circ}$ 186; alSaḥmāwī, al-Tağr, vol. I, 388; 'Alā' al-Dīn 'Alī ibn Yūsuf ibn Aḥmad al-Damašqī al-Bașrāwī, Tārīh alBașrāwī, réalisé par Akram Ḥasan al-'Ulabī, Beyrouth, 1988, 166, n³; Gaulmier Jacques, La zubda kachf al-mamālik de Halīl al-Ẓāhirī, Beyrouth, 1950, 187; Hasan al-Bāšā, al-Funūn al-islāmīya wa'lwaẓā'if 'ala al-ațār al-'arabìya, Le Caire, 1965, vol. I, 132; Aḥmad 'Abd al-Rāziq, al-Ğaiš al-mișrĩ fíl-'așr al-mamlūkī, Le Caire, 1998, 97; Loiseau Julien, "L'émir en sa maison parcours politiques et patrimoine urbain au Caire d'après les biographies du Manhal al-șāfī », Annales Islamologiques, vol. XXXVI, 2002, $130, \mathrm{n}^{\circ} 41$.

14_ Ibn Tağrībirdī, al-Nuğūm, vol. XII, 79.

15- Al-Ḥāfiẓ Ibn Ḥağar al-'Asqalānī, Inbā' al-g்umr bī anbā' al-'umr, réalisé par Ḥasan Ḥabašī, Le Caire, 1969, vol. I, 153; ibn Tağrībirdī, al-Nuğūm, vol. XI, 152; Zaīn al-'Ābidīn Muḥammad ibn Aḥmad connu par Ibn lyās, Badā'i' al-zuhūr fí waqā'i al-duhūr, réalisé par Muḥammad Muṣțafa, Le Caire, 2008, vol. I/2, 128; vol. III, 317.

16- Ibn Iyās, Badā'i', vol. III, 317.

17 - Muḥammad ibn 'Abd al-Raḥman al-Sahāwī, al-Tibr al-masbūk fĩ dail al-sulūk, réalisé par Nağwa Mușțafa Kāmil, Labība Ibrāhīm Mușțafa et revisé par Sa īd 'Abd al-Fattāḥ `Āšūr, Le Caire, 2002, vol. II, 77. 
Le legs pieux (waqf) ${ }^{18}$ du sultan al-Manșūr Qalāwūn était un des waqfs les plus grands et les plus charitables de l'Égypte. Son intendance ne fut jamais confiée à un non-musulman par peur des conspirations et aucun infirme ni malade contagieux n'y fut traité pour éviter l'infection. À l'origine, la gérance du legs pieux fut confiée au vizir avec l'assistance des plus grands émirs commandants. Mais, le vizir fut remplacé par le grand émir ${ }^{19}$; puis la gestion du waqf fut confiée au plus qualifié parmi les gens du turban en association avec le grand émir. Ce haut fonctionnaire n'avait pour autant le droit de trancher sur une affaire sans avoir recours au grand émir ainsi qu'à sa signature $^{20}$. Ibn Tag̉rībirdī souligne, pour sa part, que depuis la nomination de l'émir Ğamāl al-Dīn Aqūš comme intendant de l'hôpital Manșūrī en 723/1322, ce poste est devenu un privilège attribué à tout émir nommé chef de l'aile droite ${ }^{21}$. Cependant, après avoir visité l'hôpital al-Manșūrī pour se mettre au courant, de son état le 13 rabī II 837/27 novembre1433, le sultan al-Ašraf Barsbāy avait décidé de s'emparer de son intendance. Pour ce faire, il a décrété la non-nommination d'un successeur à Sūdūn min 'Abd al-Raḥman ${ }^{22}$ après sa revocation; puis ce fut annulé ${ }^{23}$. On raconte également que le sultan avait frappé son blason ${ }^{24}$ à la porte de l'hôpital ce qui avait

\footnotetext{
18- Le waqf, institution fréquente en pays musulman, est une dotation inaliénable, les revenus de terrains ou de bâtiments le plus souvent à fonction économique y sont définitivement dévolus à l'entretien et au fonctionnement d'institutions dispendieuses (lieu d'enseignement, soins et de culte). Le fondateur établit (le wāqif), établit devant une juridiction légale un acte à la waqfìa, stipulant quels sont les biens consacrées, au profit de quelle (s) institution (s) et dans quelle (s) conditions. Le type de biens dont les revenus sont "gelés" peut être certains terrains et bâtiments offrant des revenus comme les vergers, les bois, les moulins, les fours, les boutiques, les marchés, les bains publics, les pressoirs et les hôtels. Les actes de waqf se terminent par des conditions «šurūțt» dans lesquelles les fondations pieuses vont pouvoir fonctionner. Le document mentionne les dons en nature et les dotations en espèces aux nécessiteux, aux malades, ainsi qu'aux étudiants ou aux divers professionnels (imām, enseignants et médecins). Sylvie Denoix, "Pour une exploitation d'ensemble d'un corpus les waqfs mamelouks du Caire ": Extrait de: le waqf dans l'espace islamique outil de pouvoir socio-politique, Institut français de Damas, 1995, 41-43.

19- Le grand émir (amìr kabìr) est un titre militaire donné à un émir de 100 ou un commandant de mille. Ce titre compte parmi les titres de glorification. Al-Saḥmāwī, al-Tagir, vol. I, 388; Holt P. M, The Eastern Mediterranean Lands in the Period of the Crusades, England, 1977, 55; Hasan al-Bāša, alFunūn, vol. I, 244-249.

20- Al-Saḥmāwī, al-Tağr, vol. I, 412.

21- Ibn Tagrīibirdī, al-Manhal, vol. III, 29, n 518.

22- On verra sa biographie dans la liste des intendants de l'hôpital Manșūrī, $\mathrm{n}^{\circ} 68$.

23. Al-Maqrīzī, Durar al-'uqūd al-farīda fí tarāğim al-a yān al-mufĩda, réalisé par Maḥmūd al-Ğalīīi, Beyrouth, 2002, vol. I, 475; 'Alī ibn Dawūd al-Șairafī, Nuzhat al-nufūs wa'l-abdān, vol. III, réalisé par Ḥasan Ḥabašī, Le Caire, 1973, vol. III, 277.

24- Al-Rank est un mot persan dont le pluriel runūk, qui se pronnonce rang et qui signifie couleur. 'Alī Ibrāhīm Ḥasan, Dirāsāt fi tārīh al-Mamālīk al-Baharīya, Le Caire, 1944, 196; Ḥasan al-Bāšā, al-Funūn, vol. I, 170; Ibrāhīm Ṭarhāan, Miṣr fi 'așr al-Mamālīk al-Ğarākisa, Le Caire, 1960, 327; Aḥmad 'Abd al-Rāziq, al-Runūk al-islāmīya, Le Caire, 2001, 48.

Notons que les blasons mamelouks renferment quatre groupes différents: les blasons personnels, fonctionnels (simples ou composés), les cartouches (blasons épigraphiés) et les tamg்ā. Aḥmad 'Abd al-Rāziq, al-Runūk, 77.
} 
provoqué la réprobation d'ibn Tag̉rībirdī qui écrivit «c'était un acte inhabituel et la tradition était que ce poste fut accordé au grand émir» ${ }^{25}$.

Quant aux critères de recrutement de l'intendant de l'hôpital al-Manșūrī: il doit être choisi parmi les gens du turban et avoir une bonne connaissance des mathématiques et de l'écriture. Il parait que ces conditions n'ont pas été strictement prises en considération pour la nomination de tous les intendants. La preuve était que lors de la désignation d'al-Ḍiyā' Yūsuf al-Šàm̄̄ (nº 15) au poste en 752/1351, il avait demandé de consulter le livre du legs pieux pour être averti des modalités d'embauchage indiquées par le sultan al-Manșūr Qalāwūn. Quand il commença à les lire, il expliqua à l'ex-intendant ibn al-Ațūǔš ( $\left.n^{\circ} 14\right)$ qu'il n'avait pas les qualités requises pour occuper cet emploi, car il était un plébéien connu par la vente des cartes et ne savait rien de ces conditions. Alors, Ibn al-Ațrūš avait avoué qu'il ne connait pas les maths et qu'il est incapable d'assumer l'intendance et avait promis de ne plus occuper cette charge à nouveau ${ }^{26}$.

Malgré son importance, ce poste n'a fait l'objet d'aucune étude systématique et est resté jusqu'à nos jours très mal connu. Nous ne possédons que l'ouvrage d'Ahmad 'Îsa «Tārīh al-bimāristānāt fì'l-islām ${ }^{27}$ » publié en 1981 dans lequel il s'est contenté de signaler quatorze intendants seulement. Nous avons remarqué, par ailleurs, que l'auteur a confondu entre les intendants des deux hôpitaux Manșūrī et Nūrī. De même, il n'a presenté aucune liste chronolgique des intendants de l'hôpital Manșūrī. Hayāt Nāṣir al-Hiğğḡi avait également publié en 1988 un article intitulé "alBimāristān al-Manșūrō mudu tā 'sisahu wa hata nihāyat al-qarn al-țāmin al-hiğrī/al$r \bar{a} b^{\prime}$ 'ašar al-mila $\bar{a} \bar{l}^{28} \gg$ dans lequel elle avait jeté la lumière sur la genèse de 1'hôpital ainsi que sur son organisation administrative et financière. Elle a également signalé, à titre d'exemple, dix intendants de l'hôpital Manșūrī. Notons aussi l'ouvrage de 'Abd al-Wahhāb Mușțafa Dāhir "Imārat al-muğma'āt wa'l mabān̄̄ al-ṭibīya (albimāristanāt) fì'l-islām ${ }^{29}{ }^{\prime}$, publié en 2015 , qui avait abordé la genèse des hôpitaux, leurs genres, les normes de construction ainsi que leur évolution à travers les différentes époques islamiques.

Pour ce faire, nous avons adopté une approche inductive se basant sur les biographies, les sources mameloukes et sur l'interprétation des informations qu'elles contiennent. Nous avons eu également recours à une approche analytique dans le but d'analyser ces renseignements ainsi qu'à une approche quantitative consistant à recenser les faits et les chiffres concernant ce sujet pour aboutir à des résultats le plus

\footnotetext{
25- Ibn Taġrībirdī, al-Nuğūm, vol. XV, 36; al-Șairafī, Nuzhat al-nufūs, vol. III, 277, n 3.

26- Al-Maqrīzī, al-Sulūk, vol. IV, 133-134.

27- Aḥmad 'T̄sa, Tārīh al-bimāristānāt fĩ'l-islām, Beyrouth, $2^{\mathrm{e}}$ éd, 1981.

28- Ḥayāt Nāṣir al-Ḥiğğ̄̄, "al-Bimāristān al-Manșūrī muḍu tā'sisahu wa ḥata nihāyat al-qarn alțāmin al-hiğrī/al-rāb' 'ašar al-milādī”, Arab Journal for the Humanities, Kuwait, vol. VIII/29, 1988.

29-'Abd al-Wahhāb Mușțafa Dāhir, "Imārat al-muğma'āt wa'l-mabānī al-țibīya (albimāristanāt) fíl-islām", Mawsū'at al-'imāra fíll-islām, vol. X, 2015.
} 
possible précis et significatifs. Ces différentes approches avaient largement servi à réaliser les objectifs de cette étude formulés ainsi:

1- Déterminer l'effectif exact des intendants de 1'hôpital Manșūrī depuis sa fondation jusqu'à la chute de l'époque mamelouke (684-923/1285-1517).

2- Comparer les intendants des hôpitaux de la dynastie mamelouke baharīte à ceux de la dynastie circassienne du point de vue de leur effectif, du nombre de fois de leur nomination ainsi que de la plus longue et de la plus courte durée d'occupation des postes.

3- Examiner l'évolution de la carrière professionnelle des intendants de l'hôpital Manșūrī

4- Faire le point sur la position politique et sociale de certains trésoriers et leurs rapports avec certains sultans mamelouks.

5- Dévoiler les rapports de parenté et d'intermariage qui avaient relié certains intendants avec quelques sultans ainsi qu'avec d'autres intendants

6- Jeter la lumière sur certains intendants connus par leur pitié et leur générosité et qui ont accordé beaucoup de soins à l'hôpital Manșūrī

7- Déterminer les raisons du décès des intendants de l'hôpital Manșūrī

8- Dévoiler les raisons de la décadence qu'avait subie cette fonction

Par ailleurs, nous avons divisé l'étude en deux axes principaux basés sur les faits historiques: le premier aborde l'étude biographique des intendants de l'hôpital Manșūrī selon les biographies de l'époque mamelouke afin d'établir une liste chronologique des noms des intendants. Nous avons adopté 1'ordre chronologique grâce à la commodité qu'il présente et parce qu'il était arbitraire de choisir l'ordre alphabétique dans ce genre de listes. Nous nous sommes efforcés de décrire chaque titulaire en quatre rubriques:

1) Nom propre, le surnom (le laqab), l'épithète d'origine (la nisba) et le patronyme (la kūnīya)

2) Les dates de naissance et de décès, selon l'ampleur de l'information

3) Les dates de nomination et de révocation

4) Le degré de parenté avec d'autres personnes de la liste

Chaque fois que cela a été possible, nous avons indiqué les références biographiques du personnage dans les sources historiques.

Quant au second axe, il a été consacré à une étude analytique des critères de nomination, la durée de l'occupation des postes ainsi que des causes de renvoi. Dans cette partie, nous indiquons les raisons de décadence qu'avait subie ce poste.

Les difficultés auxquelles la chercheuse a fait face tout au long de cette étude sont considérables. En effet, malgré leur variété et leur abondance, les sources mameloukes avaient différemment traité les biographies des intendants de l'hôpital 
Manșūrī. Elles omettent de signaler les dates de nomination, de révocation et de décès d'un certain nombre d'intendants. De même, nous n'y avons trouvé que très peu d'indications sur d'autres intendants. Ceux-Ci restaient dans l'obscurité, sans avoir réussi à attirer l'attention des historiens mamelouks. Tandis que pour de nombreux intendants, ces sources nous fournissent d'abondantes informations précises qui nous ont permis d'en établir une liste quasi exhautive. Il parait que les sources ne sont intéressées qu'aux célèbres intendants.

C'est pourquoi on nous pardonnera de ne pas donner ici que les informations que nous avons pu trouver.

Premier axe: Liste chronologique des noms des intendants de l'hôpital Manșūrī

\section{1- L'eunuque ${ }^{30}$ Muršid $^{31}$ ibn ‘Abd Allah al-Manșūrī, Šihāb al-Dīn, al-Hูāzindār;}

Nommé à une date indeterminée

Révoqué à une date indeterminée

Mort le 3 dū'l-qi da 710/24 mars 1311

(Cf. al-Nuwairī, Nihāyat al-arab, vol. XXXII, 131; Abū Bakr ibn 'Abd Allah ibn Aibak al-Dawādārī, Kinz al-durar wa ğāmi' al-g̈urar, réalisé par Sa īo 'Abd al-Fattāh 'Ašūr, Le Caire, 1982, vol. IX, 210; 'Alam al-Dīn Abī Muhammad al-Qāsim ibn Yūsuf al-Birzālī al-Išbīlī al-Damašqī, al-Muqtafa 'ala kitāb al-rawḍatain connu par tārīh al-Birzālì, réalisé par 'Umar 'Abd al-Salām Tadmurī, 1 ère éd, Beyrouth, 2006, vol. III, 494, nº 1187; al-Maqrīzī, al-Sulūk, vol. II, 96; Badr al-Dīn Maḥmūd al- Ainī,

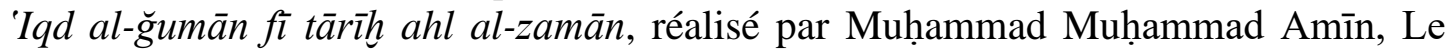
Caire, 2009, vol. V, 233)

\section{2- Ạ̣mad ibn 'Alī ibn 'Ubāda, Šihāb al-Dīn, al-Anṣārī al-Ḥalabī;}

Nommé en 707/1307

Révoqué à une date indeterminée

Mort le 16 ğumāda I 710/octobre 1310

\footnotetext{
30- C'est un mot turc dont l'origine était țābūš et qui avait plusieurs synonymes dans les sources mameloukes comme țawāšìya au singulier țawāšit, huddām au singulier ḩādim et ḩișīyān au singulier hașī. Al-Maqrīīi, Kitāb al-Mawā iż wa'l-i'tibār bī dikr al-hițaț wa'l-ațār, réalisé par Ayman Fū'ād Sayīd, London, 2003, vol. IV, 516; Ibn Šāhīn al-Ẓāhirī, Zubdat, 122; al-Sahāwī, al-Tibr, vol. I, 114, n 6; David Ayalon, The Eunuchs in The Mamluk Sultanat, Studies in Memory of Gaston Wiet, Jerusalem, 1977, 267-268.

Ils étaient un élément vital dans l'aristocratie mamelouke militaire. Ils appartenaient aux gens d'épée (arbāb al-suyūf). Plusieurs fonctions, à l'époque mamelouke, furent confiées aux eunuques tels que

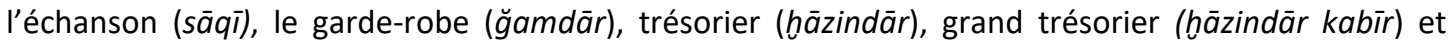
précépteur (lālā). Il y avait cinq races qui comptent parmi les principales races des eunuques : des Grecs (Rūm), Éthiopiens (Habaš), Africains de Takrūr à l'Afrique ouest ainsi que le Caucase qui était la source principale des eunuques blonds. David Ayalon, The Eunuchs, 267-273.

31. Le nom Muršid compte parmi les fréquents noms arabes donné aux eunuques à l'époque mamelouke. David Ayalon, The Eunuchs, 276.
} 
(Cf. Al-Șuqāēî̀ Tāli kitāb, 33, n 45; al-Nuwairī, Nihāyat al-arab, vol. XXXII, 129; al-Birzālī, al-Muqtafa, vol. I/2, 471, n 1117; al-Șafadī, al-Wāfì, vol. VII, 160-161; A yān al- 'aṣr wa a 'wān al-naṣr, réalisé par 'Alī Abū Zaid, Le Caire, 1998, vol. I, 297, $\mathrm{n}^{\circ}$ 149; al-Maqrīzī, al-Sulūk, vol. II, 416, 460; ibn Hağar al- 'Asqalān̄̄, al-Durar alKāmina fì a 'yān al-mi'ā al-tāmina, Haydar Abād, 1930, vol. I, 210, n 543; al- Ain̄̄, Iqd, vol. V, 222; ibn Hुațīb al-Nāṣirīya al-Halabī, al-Durr al-Muntahab fì takmilat tārīh Halab, réalisé par Aḥmad Fawzī al-Hīb, Kuwait, 2018, vol. I, 331-332, n 173)

\section{3- Aḥmad ibn Ibrāhīm ibn 'Abd al-Ġanī al-Ḥanafī Abū'l-'Abbās, Šams al-Dīn, dit al-Surū $\bar{g}^{\mathbf{3}} \mathbf{2}$;}

Né en 637/1239

Nommé à une date indeterminée

Révoqué en muḥarram 710/juin 1310

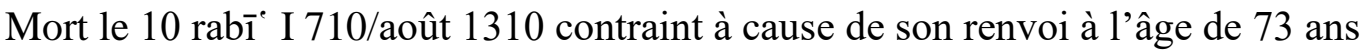

(Cf. Al-Ṣuqāē, Tālì kitāb, 8, n 7; Ismāê̄l ibn 'Umar ibn Kat̄īr, al-Bidāya wa'lnihāya, Beyrouth, 1990, vol. XIV, 58; Ibn Habīb, Durat al-aslāk fì dawlat al-atrāk, réalisé par Muḥammad Muhammad Amīn, Le Caire, 2014, vol. II, 338, $\mathrm{n}^{\circ}$ 528; Muḥ̂̄'l-Dīn Abī Muḥammad 'Abd al-Qādir ibn Abī'l-Wafā' al-Qurrašī al-Hanafī, alĞawāhir al-muḍ̄ya fi tabaqāt al-ḥanafìya, réalisé par Muḥammad 'Abd al-Fattāḥ alHilw, $2^{\mathrm{e}}$ éd, Le Caire, 1993, vol. I, 123-127, n 66; al-Maqrīzī, al-Sulūk, vol. II, 455; Ğalāl al-Dīn 'Abd al-Raḥman al-Suyūṭi, Husn al-muḥhạdara fì tārīh Miṣr wa'lQāhira, réalisé par Muḥammad Abū'l-Faḍl Ibrāhīm, 1 ère éd, Le Caire, 1968, vol. II, 184; Kamal S. Salibi, « Listes chronologiques des grands cadis de 1'Égypte sous les Mamelouks », Revue des Études Islamiques, vol. XXV, 1957, 97, nºs 3, 5.

Ibn al- Imād al-Hanbalī avait signalé sa naissance en 656/1258. Šadarāt al-diahab fì ahbār man dahab, réalisé par 'Abd al-Qādir et Mạ̣mūd al-Arnā'wṭ̂̄, 1 ère éd, Beyrouth, 1992, vol. VIII, 40)

\section{4- Abd al-Karīm ibn Hibat Allah al-Sadīd, Karīm al-Dīn, al-Kabīr al-Miṣrī Abū'l-Faḍā'il;}

Nommé le 17 ğumāda I 710/11 novembre 1310

Révoqué le 24 ğumāda II 723/1 ${ }^{\text {er }}$ juillet 1323

Étranglé à Asswān en rabīe I 724/mars 1324 à 70 ans après avoir confisqué tous ses biens

(Cf. Al-Șuqāēi Tālī kitāb, 193-194, n 350; al-Nuwairī, Nihāyat al-arab, vol. XXXII, 129; vol. XXXIII, 31-37; Šams al-Dīn Ab̄̄ 'Abdallah Muḥammad al-Dahabī, al- 'Ibar b̄̄ ahbār man ġabar, 1 ère éd, Beyrouth, 1985, vol. IV, 71; ibn Šākir al-Kutb̄̄, Fawāt al-wafìyāt wa'l-diail 'alā̄hā, réalisé par Ihsān 'Abbās, Beyrouth, 1974, vol. II, 377-

\footnotetext{
32- Surūğī d'après le nom de Surūğ qui se trouve aux alentours de Ḥirrān. 'Abdallah ibn As'ad ibn 'Alī ibn Sulaimān al-Yāf'ì, Mir'āt al-ğanān wa 'ibrat al-yaqzān fĩ ma 'rifat ma yu 'tabar min hawādit al-zamān, Beyrouth, 1993, vol. IV, 186, n 1 .
} 
383, n 298; al-Șafadī, A yān al- 'așr, vol. III, 142, n 1030; al-Wāfì, vol. XIX, 66-70, $\mathrm{n}^{\circ}$ 7218; ibn Kațīr, al-Bidāya, vol. XIV, 105, 116; ibn Habīb, Tadkirat, vol. II, 133; ibn Duqmāq, al-Ğawhar, 355; al-Nafha, 127; al-Maqrīzī, al-Sulūk, vol. II, 460; vol. III, 64, 76; ibn Hağar al-'Asqalānī, al-Durar al-kāmina, vol. II, 401-404, n 2491; ibn Tağrībirdī, al-Manhal, vol. VII, 345-350, n 1475; al-Dalīl, vol. I, 426, n 1469; alSuyūṭị, Husn, vol. II, 131; ibn al-'Imad al-Hanbalī, Šadarāt, vol. VIII, 113-114; alŠawkānī, al-Badr al-țāli bì mahāsin man ba'd al-qarn al-sābi', Le Caire, 2012, vol. I, 372-374, $\mathrm{n}^{\circ} 249$ )

\section{5- Aqūš ibn 'Abd Allah, Ğamāl al-Dīn, al-Ašrafī;}

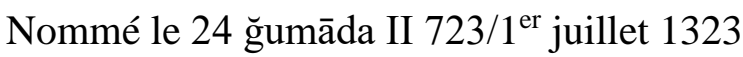

Révoqué à une date indeterminée

Mort dans la prison d'Alexandrie le 7 ğumāda I 736/22 décembre 1335

Frère de 'Alā' al-Dīn Alī ibn al-Qalānsī (nº 6)

(Cf. Al-Șafadī, al-Wāfì, vol. IX, 195-197, n 1924; A'yān al-'aṣr, vol. I, 578-582, nº 314; al-Maqrīzī, al-Sulūk, vol. III, 64, 89, 208.

Cependant il a signalé sa nommination dans son ouvrage al-Muqaffa au cours de rabī'II 723/avril 1323. Al-Muqaffa al-kabīr, réalisé par Muḥammad al-Ya lāwī, $1^{\text {ère }}$ éd, Beyrouth, 1991, vol. II, 141-147, n 816; ibn Hağar al- Asqalān̄̄, al-Durar alkāmina, vol. I, 395-396, n 1023; al- Ain̄̄, 'Iqd, vol. V, 40, n 4; ibn Taġrībirdī, alManhal, vol. III, 27-30, $\mathrm{n}^{\circ}$ 518; al-Dalīl, vol. I, 146, $\mathrm{n}^{\circ}$ 517; Gaston Wiet, Les biographies du manhal safi, Le Caire, 1932, 74, $\mathrm{n}^{\circ}$ 512; Aḥmad 'Isa, al-Bimāristānāt, 95)

\section{6- 'Alī ibn Muḥammad ibn Muḥammad Abū'l-Ḥasan, ‘Alā' al-Dīn, Ibn al- Qalānsī;}

Né en 673/1274

Nommé le 15 dū'l-hịğğa 730/30 septembre 1330

Révoqué à une date indeterminée

Mort en 736/1336 à l'âge de 63 ans

Frère de Ğamāl al-Dīn Aqūš al-Ašrafī (n 5$)$

(Cf. Al-Șafadī, al-Wāfì, vol. XXII, 88, nº 84; Ibn Katīir, al-Bidāīya, vol. XIV, 154)

\section{7- Uțmān ibn Muṣtafa ibn Ibrāhīm ibn Sūlaimān, Faḩr al-Dīn, al-Mārdin̄̄, dit Ibn al-Turkumānī;}

Né en 660/1262

Nommé à une date indeterminée

Mort en fonction le 11 rağab 731/20 avril 1331 à 71 ans

Père d'Aḥmad ibn Faḥr al-Dīn 'Uțmān al-Mārdinī (nº 8 ) 
(Cf. Ibn Kațīr, al-Bidāīya, vol. XIV, 156; ibn Habīb, Tadkirat, vol. II, 213-214; alQurašì, al-Ğawāhir al-muḍ̄ya, vol. II, 521-522, n 927; al-Maqrīzī, al-Sulūk, vol. III, 150; ibn Hağar al- Asqalān̄̄, al-Durar al-kāmina, vol. II, 435, n 2565; ibn Tağrībirdī, al-Nuğùm, vol. IX, 290-291; al-Manhal, vol. VII, 412, n 1519; al-Dalīl, vol. I, 438, n 1513; Abū Fidā' Zaīn al-Dīn Qāsim ibn Qaṭlwbug̀ā al-Sūdūnī, Tāğ al-

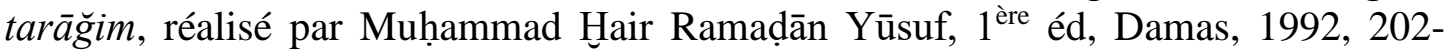
203, n 159; al-Suyūṭ̂̄, Husn, vol. I, 469, n 30; Mạ̣mūd ibn Sulaimān al-Kafawī,

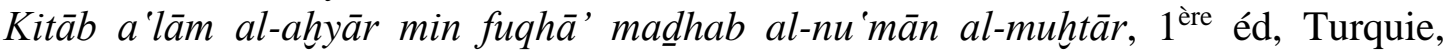
2017, vol. III, 334-335, n 527; Taqī al-Dīn ibn 'Abd al-Qādir al-Ġizī al-Mișrī alHanafī, al-Ṭabaqāt al-Sunnīya fì tarāğim al-hanafìya, réalisé par 'Abd al-Fattāh Muhammad al-Hilw, $1^{\text {ère }}$ éd, L'Arabie Saoudite, 1983, vol. I, 389-390, n 240; Hāă Halīfa, Kašf al-zunūn 'an asāmī al-kutb wa'l-funūn, Beyrouth, 1992, vol. II, 1832; Ab̄̄ al-Hasanāt Muhammad 'Abd al-Hay al-liknwā̄ al-Hindī, al-Fawā'id al-bahīya fì tarāğim al-Hanafı̀ya, réalisé par Muḥammad Badr Abū Firās al-Na sānī, Le Caire, 1906, 115; ibn Hațīb al-Nāṣirīya, al-Durr al-Muntahab, vol. I, 325-326, n 165; Gaston Wiet, Les biographies, 220, $\mathrm{n}^{\circ} 1507$ )

\section{8- Aḥmad ibn Faḩr al-Dīn 'Uțmān ibn Muṣtafa ibn Sulaimān, al-Mārdinī al- Mișri, dit al-Turkumānī;}

Né en $681 / 1382$

Nommé en rağab 731/avril 1331

Révoqué à une date indeterminée

Mort en ğumāda I 744/octobre 1343 à 63 ans

(Cf. al-Șafadī, al-Wāfî, vol. VII, 121-122, n 778; Ibn Katīr, al-Bidāīya, vol. XIV, 156; Ab̄̄ al-Wafā' al-Qurašì, al-Ğawāhir al-muḍ̄ya, vol. I, 198-199, n 139; ibn

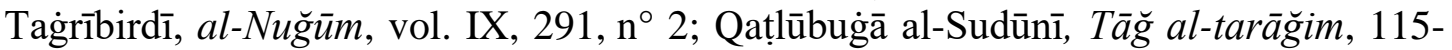
116, n 44; al-Suyūṭ̂̀, Husn, vol. I, 469, n 31; al-Kafawī, Kitāb i 'lām al-ahyār, vol. III, 508, n 610; al-Ġizì, al-Ṭabaqāt al-sunnīya, vol. I, 386-390, n 240; ibn al- 'Imād al-Ḥanabalī, Ša darāt, vol. VIII, 243; Abī al-Hasanāt al-Hind̄i, al-Fūā'id, 25-26; Gaston Wiet, Les biographies, 29, n 199)

Fils de Faḩr al-Dīn 'Uțmān al-Mardinī (n 7 )

\section{9- Abū Sa īd Sanğar, ‘Alam al-Dīn, al-Ğāwlī;}

Né en 653/1255

Nommé en muharram 734/septembre 1333

Révoqué en 743/1342

Mort le 9 ramaḍān 745/14 janvier 1345 à 92 ans

(Cf. Al-Șafadī, A yān al- 'așr, vol. I, 579, n 314; al-Wāfì, vol. XV, 292-293, n 5218; Tāğ al-Dīn al-Subkī, Țabaqāt al-šăf'ōya al-kubra, réalisé par 'Abd'l-Fattāḥ al-Hilw et Maḥmūd Muhammad al-Ṭanāhīi, $1^{\text {ère } e ́ d, ~ L e ~ C a i r e, ~ 1964, ~ 41, ~ n º ~ 1362 ; ~ a l-S u ̄ d u ̄ n ̄ i, ~ T a ̄ g ̆ ~}$ al-tārāğim, 395, n 174; ibn Haț̣ỉb al-Nāṣirīya, al-Durr al-muntahab, vol. III, 1114, n ${ }^{\circ}$ 598) 


\section{0- Ğankalī ibn Muḥammad ibn al-Bābā ibn Ğankalī ibn Ḩalīl, Badr al-Dīn dit ibn al-Bābā al-'Ağgīi;}

Né en $675 / 1276$

Nommé le 3 șafar 743/8 juillet 1342

Révoqué à une date indeterminée

Mort le 17 dū'l-hịğğa 746/11 avril 1346 à 71 ans

(Cf. Al-Ṣafadī, al-Wāfì, vol. XI, 154-155, n 2938; A 'yān al-'așr, vol. II, 163; Dìyyūl al-'ibar (al-Ḥūssain̄i), vol. IV, 140; al-Maqrīzī, al-Sulūk, vol. III, 378; vol. IV, 22. Il

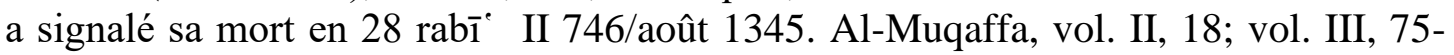
77, n 1097; ibn Ḥağar al- 'Asqalānī, al-Durar al-kāmina, vol. I, 539-540, n 1461.

Ibn Qāḍi Šuhba avait mentionné sa nommination en muharram 743/juin 1342. Tārīh ibn Qāậ̀ Šuhba, réalisé par 'Adnān Darwī̌s, Damas, 1977, vol. I, 300; ibn Taġrībirdī, al-Nuğüm, vol. X, 80; al-Manhal, vol. V, 22-25, n 864; al-Dalīl, vol. I, 251, n 862; ibn Hațīb al-Nāṣirīya, al-Durr al-muntahab, vol. II, 837-838, n 451; Ahmad 'Isa, alBimāristānāt, 97)

\section{1- Yūsuf ibn Abī Bakr ibn Muḥammad, Ḍīyā' al-Dīn, al-Šāmī, dit ibn Hูaṭīb Bait al-abār;}

Nommé en rabī' II 745/août 1344

Révoqué le 21 dū'l-qi' da 745/26 mars 1345

Mort en dū'l-hịğğa 761/octobre 1360

(Cf. Mūssa ibn Muḥammad ibn Yahịa al-Yūsufì, Nuzhat al-nāzūir fì sirat al-malik alNāssir, Beyrouth, 1986, 296, n 3; al-Șafadī, al-Wäfì, vol. XXIX, 69-72, nº 63; A yā̄n al-'așr, vol. II, 562; al-Maqrīzī, al-Sulūk, vol. III, 414, 420; vol. IV, 249; Aḥmad 'Abd al-Rāziq, «La hisba et le muḥtasib en Égypte au temps des Mamlūks », Annales Islamologiques, Le Caire, vol. XIII, 1977, 119-120, $\mathrm{n}^{\text {os }} 8,10$, 12; Hayāt Nāṣir alḤiğğ̄ì, « al-Bimāristān al-Manșūrī», AJH, vol. VIII/29, 27)

\section{2- 'Alī ibn Muḥammad ibn al-Ațrūšs, 'Alā' al-Dīn, al-Saqațī;}

Nommé le 21 dū'l-qi'da 745/26 mars 1345

Révoqué à une date indeterminée

Mort en 758/1357

(Cf. Al-Maqrīzī, al-Sulūk, vol. III, 420; vol. IV, 233; Aḥmad 'Abd al-Rāziq, «La hisba », AnIsl, vol. XIII, 141, n 13; Hayāt Nāṣir al-Hiğğğī, « al-Bimāristān alManșūrī », $A J H$, vol. VIII/ 29, 27)

\section{3- Arg̀ūn al-'Alā'ī, Saif al-Dīn, al-Nāṣirī;}

Nommé en muḥarram 746/mai 1345

Révoqué en muharram 747/mai 1346 
Assassiné à Alexandrie en ğumāda I 748/août 1347 après son arrestation

(Cf. Al-Șafadī, al-Wāfí, vol. VIII, 230, n 1443; Maqrīzī, al-Sulūk, vol. IV, 24, 34, 67; al-Muqaffa, vol. II, 25-26, n 702; al-Hुițaț, vol. IV/2, 701; Ibn Ḥăgar al- Asqalān̄̄, alDurar al-kāmina, vol. I, 353, $\mathrm{n}^{\circ} 875$.

Ibn Tag̉rībirdī avait signalé sa nomination après la mort de Ğankalī al-Bābā en 746/1345. Al-Nuğ̄ùm, vol. X, 126; al-Dalīl, vol. I, 105; Aḥmad 'Isa, al-Bimāristānāt, 97)

\section{4- ‘Alī ibn Muḥammad ibn al-Ațrūšs, ‘Alā' al-Dīn, al-Saqaṭī;}

Rénommé à une date indeterminée

Révoqué le 14 muḥarram 752/13 mars 1351

Mort en 758/1357

(Cf. Al-Maqrīzī, al-Sulūk, vol. IV, 133, 233; Aḥmad 'Abd al-Rāziq, « La ḥisba », AnIsl, vol. XIII, 141, $\mathrm{n}^{\circ} 13$ )

\section{5- Yūsuf b, Abī Bakr ibn Muḥammad, Ḍīyā' al-Dīn, al-Šāmī, dit ibn Haṭīb Bait al-abār;}

Rénommé le 14 muḥarram 752/13 mars 1351

Révoqué à une date indeterminée

Mort en ramaḍān 759/août 1358

(Cf. Al-Yūsufī, Nuzhat al-nāzēir, 296, n 3; al-Ṣafadī, al-Wāfì, vol. XXIX, 69-72, n 63; A yān al-'aṣr, vol. II, 562; al-Maqrīzī, al-Sulūk, vol. IV, 133, 237; Aḥmad 'Abd al-Rāziq, «La ḥisba », AnIsl, vol. XIII, 119-120, n $^{\text {os }}$ 8, 10, 12; Ahmmad 'Isa, alBimāristānāt, 98; Hayāt Nāṣir al-Ḥiğğ̣̄, « al-Bimāristān al-Manșūrī », AJH, vol. VIII/ 29, 27)

\section{6- Azdumur, 'Izz al-Dīn, al-Nāṣirī dit Abī Daqn al-Ḩāzindār;}

Nommé en ramaḍān 759/août 1358

Révoqué à une date indeterminée

Mort en rabīi II 769/décembre 1367

(Cf. Al-Maqrīzī, al-Sulūk, vol. IV, 238, 320; Ibn Qāḍ̄i Šuhba, Tārīh, vol. II, 134; vol. III, 325; Ibn Iyās, Badā'i', vol. I/2, 78; Hayāt Nāșir al-Ḥiğğ̄i, « al-Bimāristān alManșūrī », AJH, vol. VIII/29, 28; Sāmīya 'Alī Maișlhịi, «al-Ḩāzindār fî̀l- 'așr almamlūkī (648-923/1250-1517) dirāsa tārīhīya hạạāīya », The Historical Researches \& Studies Center, Université du Caire, 2009, X, 39; Rania Ossama, Les trésoriers à l'époque mamlūke en Égypte et leurs œuvres architecturales et artistiques (648-923/ 1250-1517), Thèse de doctorat, Faculté des Lettres/ Université de Ain Chams, 2013, 379-380, $\mathrm{n}^{\circ} 18$ )

\section{7- Asundumur ibn `Abd Allah, Saif al-Dīn, al-Nāṣirī;}

Nommé à une date indeterminée 
Révoqué à une date indeterminée

Mort en ramaḍān 769/mai 1368 dans la prison d'Alexandrie

(Cf. Walī al-Dīn Abī Zar`a Aḥmad ibn 'Abd al-Raḥīm ibn al-Ḥussaīyn ibn al- Irāqī, al-Dail 'ala al-'ibar fì habar man gabar, réalisé par Șāliḥ Mahdī 'Abbās, 1 ère éd, Beyrouth, 1989, 233; al-Maqrīzī, al-Sulūk, vol. IV, 320; Ibn Hağar al- Asqalānī, alDurar al-kāmina, vol. I, 413, n 982; ibn Tağrībirdī, al-Nŭ̆̄um, vol. XI, 103; alManhal, vol. II, 440-443, n 464; al-Dalīl, vol. I, 132, n 463; ibn Iyās, Badā'i ', vol. I/2, 78-79; Gaston Wiet, Les biographies, 66, $\mathrm{n}^{\circ}$ 459)

\section{8- Aqtamur ${ }^{33}$ ibn `Abd Allah, Saif al-Dīn, dit Aqtumur ibn ‘Abd al-Ġanī;}

Nommé à une date indeterminée

Révoqué en 762/1361

Mort le 29 ğumāda II 783/21 décembre 1381

(Cf. Daīyūl al- 'ibar (al-Hussainī), vol. IV, 181; al-Maqrīzī, al-Sulūk, vol. V, 132; ibn Hağar al- Asqalānī, al-Durar al-kāmina, vol. I, 392, n 1008; Inbā', vol. I, 243-244, $\mathrm{n}^{\circ}$ 12; ibn Tağrībirdī, al-Nuğūm, vol. XI, 4, 219; al-Manhal, vol. II, 493, n 498; alDalīl, vol. I, 141, n 497; ibn Iyās, Badā' 'i', vol. I/2, 289; Muḥammad 'Abd al-Ġan̄̄ al-Ašqar, Nā'ib al-salțana al-mamlūkīya fì Miṣr, Le Caire, 1999, 385, n 37)

\section{9- Qaštamur ibn ‘Abd Allah al-Manșūrī;}

Nommé en ğumāda I 762/mars 1361

Révoqué à une date indeterminée

Tué en combat en 770/1369 en Alep

(Cf. Ibn Hağar al- Asqalān̄̄, al-Durar al-kāmina, vol. III, 249, n 634; ibn Tag̉rībirdī, al-Nuğ̄um, vol. XI, 4, 106; al-Dalīl, vol. II, 543, n 1864; al-Ašqar, Nā'ib al-salțana, $382, \mathrm{n}^{\circ} 32$ )

\section{0- Ibrāhīm ibn Muḥammad ibn Abī Bakr, Burhān al-Dīn, al-Sa dī, al-Ahnnā'ī;}

Nommé à une date indeterminée

Révoqué en șafar 763/décembre 1361

Mort le 2 rağab 777/27 novembre 1375

(Cf. Ibn al-'Irāqī, al-Dֵaīl, 89; al-Maqrīzī, al-Sulūk, vol. IV, 261; Durar al-'uqūd, vol. I76-77, $\mathrm{n}^{\circ}$ 19; ibn Hağar al- Asqalānī, al-Durar al-kāmina, vol. I, 58-59, $\mathrm{n}^{\circ}$ 156; Inbā', vol. I, 108, $\mathrm{n}^{\circ} 3$; Raf' al-'așr 'an quḍāt miṣr, Le Caire, 1988, vol. I, 34-35, $\mathrm{n}^{\circ}$ 6; Ibn Taġrībirdī, al-Nuğ̄um, vol. XI, 136; al-Manhal, vol. I, 146-147, nº 69; al-Dalīl, vol. I, 26, n 68; Qaṭūbugiā al-Sūdūn̄̄, Tāğ al-tarāğim, 461, n 86; Šams al-Dīn

\footnotetext{
33- Aqtumur se compose de deux syllabes «Aq" qui signifie blanc et "tamur " qui siginifie fer. Cf. J. Sauvaget, "Noms et surnoms de mamelouks", Journal of the Asiatic Society of Great Britain and Ireland, vol. CCXXXVIII, 1950, 37, $\mathrm{n}^{\circ} 21$; David Ayalon, "Names, Titles and Nisbas of the Mamelouks", Israel Oriental Studies, 1975, 200.
} 
Muḥammad ibn 'Abd al-Raḥman al-Sahāwī, Wă̌̄z al-kalām fì'l-dail 'ala-dūwal al-

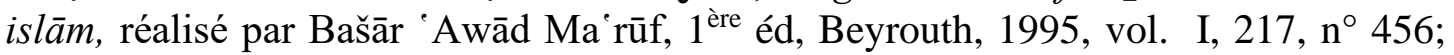
al-Suyūṭ̂̄, Husn, vol. I, 461, nº 86; ibn Iyās, Badā' ’́, vol. I/1, 587; Aḥmad Bābā al-

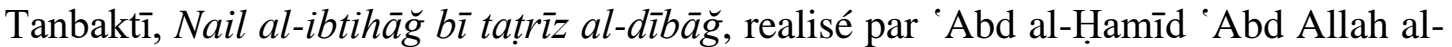
Harāma, $1^{\text {ère } e ́ d, ~ T r i p o l i, ~ 1989, ~ 47, ~ n ~ 15 ; ~ i b n ~ a l-' I m a ̄ d ~ a l-H a n b a l i ̄, ~ S ̌ a ~ d a r a ̄ t, ~ v o l . ~ V I I I, ~}$ 431.

Al-Maqrīzī avait remonté la date de sa mort le 5 muḥarram 777/6 juin 1375. Al-Sulūk, vol. IV, 391; Salibi, «Listes », REI, vol. XXV, 111; Aḥmad 'Abd al-Rāziq, «La hisba », AnIsl, vol. XIII, 141, ${ }^{\circ} 17$ )

21- Abū 'Abd Allah ibn Bahā' al-Dīn, Tāŏ al-Dīn, al-Mālikī, dit ibn Šāhid al-Ğamālī;

Nommé en șafar 763/décembre 1361

Révoqué à une date indeterminée

Mort le $1^{\text {er }}$ ša bān $772 / 18$ février 1371

(Cf. Al- Maqrīzī, al-Sulūk, vol. IV, 261; ibn Tag̉rībird̄̄, al-Nuğūm, vol. XI, 118; ibn Iyās, Badā'i', vol. I/1, 587)

\section{2- Mankalī Bug̀ā ibn ‘Abd Allah, Saif al-Dīn, al-Šamsī;}

Né en $724 / 1324$

Nommé en rabīe I 769/novembre 1367

Mort en fonction en ğumāda I 774/novembre 1371 à l'âge de 50 ans

(Cf. Ibn al- 'Irāqī, Dail, 234, 361; Ibn Duqmāq, al-Nafḥa, 211, n 76; al-Maqrīz̄i, alSulūk, vol. IV, 356; ibn Hağar al- 'Asqalānī, al-Durar al-kāmina, vol. IV, 367, n 998; Inbā', vol. I, 54-55, $\mathrm{n}^{\circ}$ 45; ibn Tag̉ībird̄̄, al-Dalīl, vol. II, 744-745, $\mathrm{n}^{\circ}$ 2542; al-

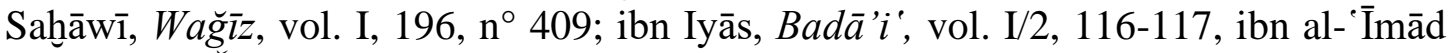
al-Hanbalī, Šadarāt, vol. VIII, 407; Muḥammad Rāgìb al-Ṭabāh al-Halabī, I'lām alnubalā' bī tarīh halab al-šahbā', réalisé par Muḥammad Kamāl, $2^{\mathrm{e}}$ éd, Alep, 1988, 362-363; ibn Huațīb al-Nāṣirīya, al-Durr al-muntahab, vol. V, 2513-2514, n 1570)

\section{3- Muḥammad ibn Aḥmad ibn yaḥīya, al-Turkumānī al- 'Ibṭinī, dit Nāṣir al-Dīn A $\dot{\mathbf{g}} \mathbf{a} ;$}

Mandaté au temps de Mankalī Bug̣ā al-Šamsi

Révoqué à une date indeterminée

Perdu dans la bataille al-Link contre Taymūr Lank en Syrie en 803/1400

(Al-Șairafī, Nuzhat al-nufūs, vol. II, 123-124, n 339; Šams al-Dīn Muhammad ibn 'Abd al-Raḥman al-Sahāw̄ī, al-Ḍaw' al-lāmi' li 'ahl al-qarn al-tāsi ', Beyrouth, 1992, vol. VI, 294, $\mathrm{n}^{\circ}$ 981)

\section{4-Ulğāy ibn 'Abd Allah, Saif al-Dīn, al-Yusūfĩ al-Nāṣirī;}

Nommé en ğumāda II 774/décembre 1372

Révoqué à une date indeterminée 
Noyé dans le Nil le 8 muharram 775/30 juillet 1373

(Cf. Ibn al-'Irāqī, al-Daīl, 367; al-Maqrīzī, al-Sulūk, IV, 356; ibn Duqmāq, alĞawhar, 427-428; al-Nafha, 212, n 78; ibn Hağar al-'Asqalān̄̄, al-Durar al-kāmina, vol. I, 231, 433; Inbā', vol. I, 56-58, 64, n 9; ibn Taġrībird̄̄, al-Nuğūm, vol. XI, 57-

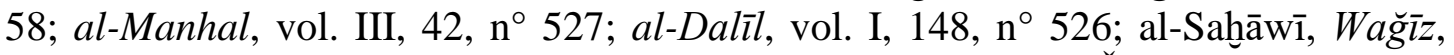
vol. I, 197-198, n 411; Zain al-Dīn 'Abd al-Bāsiṭ ibn Ḩal̄il ibn Šāhīn al-Ẓāhirī, Nail al-amal fì dail al-dīwal, réalisé par 'Umar 'Abd al-Salām Tadmurī, Beyrouth, 2015, vol. II, 54; ibn Iyās, Badā' 'i', vol. I/2, 119; ibn Hुâtị̄b al-Nāșirīya, al-Durr almuntahab, vol. II, 627, $\mathrm{n}^{\circ}$ 341; Rania Ossama, Les trésoriers, 384, $\mathrm{n}^{\circ} 27$ )

\section{5- Ibrāhim ibn Muḥammad ibn Abī Bakr, Burhān al-Dīn, al-Sa ' dī al-Ahnnā'ī;}

Mandaté en ğumāda II 774/décembre 1372

Révoqué à une date indeterminée

(Cf. Ibn al-'Irāqī, al-Ḍail, 89; al-Maqrīzī, al-Sulūk, vol. IV, 391; Durar al- 'uqūd, vol. I, 76-77, n 19; ibn Hağar al- 'Asqalānī, al-Durar al-kāmina, vol. I, 58-59, n 156; Inbā', vol. I, 108, $\mathrm{n}^{\circ} 3$; Raf' al-iṣr, vol. I, 34-35, $\mathrm{n}^{\circ}$ 6; ibn Taġrībirdī, al-Nuğùm, vol. XI, 136; al-Manhal, vol. I, 146-147, n 69; al-Dalīl, vol. I, 26, n 68; al-Saḩāwī, Wă̆ḡz, vol. I, 217, n 456; al-Suyūțì, Husn, vol. I, 461, n 86; al-Tanbiktī, Nail alibtihāğ, 47, n 15; ibn al-'Imād al-Hanbalī, Ša darāt, vol. VIII, 438; Salibi, « Listes », REI, vol. XXV, 111, n 10; Aḥmad 'Abd al-Rāziq, « La ḥisba », AnIsl, vol. XIII, 141, $\left.\mathrm{n}^{\circ} 17\right)$

\section{6- Šākir ibn Ibrāhīm, Karīm al-Dīn, al-Qibṭi, dit Ibn al-Ġannām;}

Né en $723 / 1323$

Nommé le 22 ğumāda II 775/9 décembre 1373

Révoqué le 20 rağab 775/5 janvier 1374

Mort le 27 šawwāl 823/5 novembre 1421 à 100 ans

(Cf. Al-Maqrīzī, al-Sulūk, vol. IV, 352, VII, 22; ibn Iyās, Badā'i', vol. I/2, 128; vol. II, 57; Aḥmad 'Abd al-Rāziq, «Le vizirat et les vizirs au temps des Mamlūks », Annales Islamologiques, Le Caire, 1980, vol. XVI, $\mathrm{n}^{\text {os }}$ 58, 62, 73)

\section{7- Ibrāhīm ibn Bahā' al-Dīn ibn ‘Abd Allah, Burhān al-Dīn, al- Ḥilī;}

Nommé le 20 rağab 775/5 janvier 1374

Révoqué le 5 šawwāl 775/20 mars 1374

Mort le 5 muharram 777/6 juin 1375

(Cf. Al- 'Irāqī, al-Dainl, 403; al-Maqrīzī, al-Sulūk, vol. IV, 360, 365, 366; ibn Hağar al'Asqalānī, Inbā', vol. I, 108, n 2; ibn Qāḍī Šuhba, Tārīh, vol. III, 433; ibn Iyās, Badā' $i$, vol. I/2, 153)

28-'Abd al-Karīm Šākir ibn Ibrāhīm, Karīm al-Dīn, al-Qibṭī, dit ibn al-Ġannām; Renommé le 5 šawwāl 775/20 mars 1374 
Révoqué en muḥarram 776/juin 1374

(Cf. Al-Maqrīz̄i, al-Sulūk, vol. IV, 366; ibn Hağar al- 'Asqalānī, Inbā', vol. I, 24; vol. III, 228-229, n 4; ibn Taġrībirdī, al-Nuğ̄um, vol. XIV, 162-163; al-Șairafī, Nuzhat alnufūs, vol. II, 483, n' 597; al-Saḩāwī, al-Ḍaw', vol. V, 21, n 73; ibn Iyās, Badā' $i$ ', vol. I/2, 131; Gaston Wiet, Les biographies, 211, n 1455; Aḥmad 'Abd al-Rāziq, «Le vizirat », AnIsl, vol. XVI, 205, $\mathrm{n}^{\circ}$ 60)

\section{9- Aydumur ibn 'Abd Allah al-Nāṣirī, 'Izz al-Dīn, al-Anūkī al-Dawādār;}

Né en $716 / 1316$

Nommé en muharram 776/juin 1374

Mort en fonction en dū'l-qi da 776/avril 1375 à 60 ans

(Cf. Ibn Duqmāq, al-Ğawhar, 428; al-Nafha, 213; al- 'Irāq1̄, al-Dail, vol. II, 387-388; al-Maqrīzì, al-Sulūk, vol. IV, 377; al-Muqaffa, vol. II, 201-202, n 880/2; Durar al'uqūd, vol. I, 437, $\mathrm{n}^{\circ}$ 354; ibn Taġrībirdī, al-Nuğ̄um, vol. XI, 134; al-Manhal, vol. III, 178, n 605; al-Dalīl, vol. I, 169, n 604; ibn Qāḍ̄ Šuhba, Tārīh, vol. III, 457; Muḥammad ibn Muḥammad ibn Abā Muḥammad ibn Fahd al-Hāšaimī al-Makkī, Laḥ al-alhāz bi dail țabaqāt al-ḥufāz, Beyrouth, 2009, 163; ibn Haṭ̂̄b al-Nāṣirīya, alDurr al-muntahab, vol. II, 651, n 358.

Ibn Hağar al- 'Asqalān̄̄ avait mentionné qu'il est mort à l'âge de 70 ans. Inbā', vol. I, $\left.83, \mathrm{n}^{\circ} 25\right)$

\section{0-Ṣargitmiš ${ }^{34}$ ibn 'Abd Allah, Saif al-Dīn, al-Ašrafī al-Hูāṣkī;}

Nommé le 19 dū'l-qi da 776/22 avril 1375

Révoqué à une date indeterminée

Assassiné dans la prison d'Alexandrie le 4 dū'l qi da 778/15 mars 1377

(Cf. Al-Maqrīz̄i, al-Sulūk, vol. IV, 377; vol. V, 25; ibn Hağar al- 'Asqalān̄̄, al-Durar al-kāmina, vol. II, 305, n 1978; Inbà', vol. I, 139, n 34; ibn Tag̀rībirdī, al-Manhal, vol. VI, 341-342, n 1216; al-Dalīl, vol. I, 353-354, n 1213; ibn Qāḍ̄ Šuhba, Tārīh, vol. III, 525; al-Sahāwīi, al-Ḍaw', vol. III, 322, n 1235; Aḥmad 'Isa, al-Bimāristānāt, 99)

\section{1- Ṭaštamur ${ }^{35}$ ibn `Abd Allah al-Muḥmmadī al-Laffāf;}

Nommé le 12 dū'l-qi da 778/23 mars 1377

Arrêté et emprisonné le 5 muharram 779/14 mai 1377

\footnotetext{
34- Șargitmiš ou Șarqitmiš, «il a pendu, été suspendu ou plutôt «il est tombé à terre » ou « il a dégoutlé ", "il s'est laissé glisser à terre ». Ce nom insolite doit se justifier par quelque incident ayant marqué le début de la vie de l'enfant. J. Sauvaget., "Noms», JA, vol. CCXXXVIII, 49, $\mathrm{n}^{\circ} 117$.

35- Ṭaštamur se compose de deux syllables: "Ṭāšs" qui signifie pierre et "tamur» qui signifie fer. J. Sauvaget, "Noms », JA, vol. CCXXXVIII, 50, n 133.
} 
Mort en muḥarram 779/mai 1377 affecté par l'épidémie de peste

Beau-fils de Saif al-Dīn Qarțāy al-Turkī (n³2)

(Cf. Ibn al-' Irāqīe al-Dֵā̄l, 465; Ibn Duqmāq, al-Ğawhar, 445; al-Maqrīzī, al-Sulūk, vol. V, 42; ibn Hağar al-'Asqalānī, Inbā', vol. I, 131, 153, 156, 165, $\mathrm{n}^{\circ}$ 23; ibn Tağrībirdī, al-Manhal, vol. VI, 294, n 1246; al-Dalīl, vol. I, 362, n 1243; al-Saḩāwī,

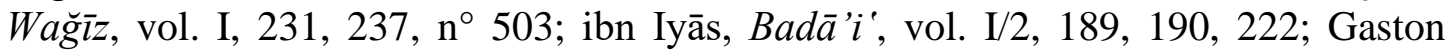
Wiet, Les biographies, 176, $\mathrm{n}^{\circ} 1235$ )

\section{2- Qarțāy ibn Abd Allah, Saif al-Dīn, al-Turkī al-Ṭāzī;}

Nommé le 19 muharram 779/28 mai 1377

Révoqué le 24 șafar 779/2 juillet 1377

Assassiné dans la prison d'al-Marqab à Tripoli en ramaḍān 779/janvier 1378 et sa tête fut envoyée au Caire

Beau-père de Ṭaštamur al-Laffāf $\left(n^{\circ} 31\right)$

(Cf. Al-Maqrīzī, al-Sulūk, vol. V, 28, 43; ibn Hağar al-'Asqalān̄̄, Inbā', vol. I, 153, 166, n 32; ibn Tagrībirdī, al-Nuğ̄um, vol. XI, 152-153, 191; al-Dalīl, vol. II, 540, n 1854; al-Sahāwī, Wağ̄iz, vol. I, 231; ibn Iyās, Bad̄̄ 'i ', vol. I/2, 202, 218; Hiba Yūsuf,

«Le chef de la ronde au temps des Mamlūks (rā's nawbat al-nawb)», Journal of Association of Arab Universities for Tourism and Hospitality, vol. VIII/2, décembre 2011, 90, $\mathrm{n}^{\circ}$ 17)

\section{3- Inabak ibn 'Abd Allah, 'Izz al-Dīn, al-Badrī;}

Nommé le 28 șafar 779/7 juillet 1377

Révoqué en rabīe I 779/juin 1377 puis emprisonné dans la prison d'Alexandrie

Assassiné dans la prison d'Alexandrie le 10 muḥarram 780/9 mai 1378

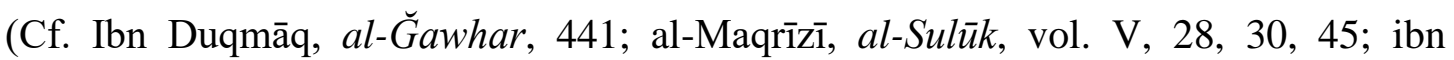
Tağrībirdī, al-Nuğūm, vol. XI, 153; al-Manhal, vol. III, 221-224, n 629; al-Dalīl, vol. I, 177, n 628; ibn Iyās, Badā' ' ${ }^{\circ}$, vol. I/2, 204, 222)

\section{4- Bahādur al-Ğamālī, Saif al-Dīn, al-Ustādār, dit al-Mušarraf;}

Nommé le $1^{\text {er }}$ rabīe I 779/28 juin 1377

Révoqué le 26 ğumāda I 779/21 septembre 1378

Mort le 14 dū'l qi da 786/28 décembre 1384

(Cf. Ibn Duqmāq, al-Ğawhar, 425; al-Nafha, 209; al-Maqrīzī, al-Sulūk, vol. V, 37; ibn Hağar al- Asqalānī, al-Durar al-kāmina, vol. I, 496, n 1353; ibn Qāḍī Šuhba, Tārīh, vol. III, 141; ibn Tağrībirdī, al-Manhal, vol. III, 432-433, n 707; al-Dalīl, vol. I, 200-201, n 705; 'Abd al-Bāsit ibn Šāhīn al-Ẓāhirī, Nail, vol. II, 9, 10, 222; alSahāwī̄, Wağ̄iz, vol. I, 271, n 580; ibn Iyās, Badā 'í, vol. I/2, 354; Marwa Hamdī, alUstādārīya in the Mamlūk Period and their Architectural and Artistic Works in Egypt,

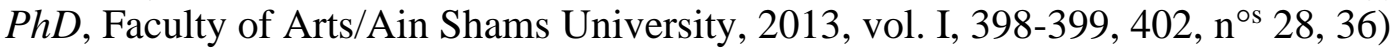




\section{5- Tamurbāy ibn 'Abd Allah, Saif al-Dīn, al-Tamurtāšī al-Manșūrī;}

Nommé le 26 ğumāda I 779/21 septembre 1378

Révoqué à une date indeterminée

Mort le $1^{\text {er }}$ gumāda I 785/2 juillet 1383 à Șafad

(Cf. Ibn al-' Irāqī, al-Dֵā̄l, 463; al-Maqrīzī, al-Sulūk, vol. V, 37, 48, 151; ibn Hağar al'Asqalānī, Inbā', vol. I, $282 \mathrm{n}^{\circ}$ 13; ibn Taġrībirdī, al-Nuğ̄ùm, vol. XI, 297-298; alManhal, vol. IV, 88-89, n 777; al-Dalīl, vol. I, 221, n 775; ibn Hațīb al-Nāṣirīya, alDurr al-Muntahab, vol. II, 791-792, n 432; Gaston Wiet, Les biographies, 111, $\mathrm{n}^{\circ}$ 767; Hiba Yūsuf, «Le chef de la ronde », JAAUTH, vol. VIII/ 2, 90, n²1)

\section{6- Muḥammad ibn 'Uțmān, Badr al-Dīn, al-Anfahsī;}

Nommé à une date indeterminée

Révoqué le 29 rabīi II 780/25 août 1378

Mort à une date indeterminée

(Cf. Al-Maqrīzī, al-Sulūk, vol. V, 50)

\section{7- Baraka ibn `Abd Allaha, Zain al-Dīn, al-Ğūbānī al-Yalbuğāwī;}

Nommé le 29 rabīi II 780/25 août 1378

Il a mandaté Ğamāl al-Dīn al- Ağamī dans le même jour de sa nomination

Assassiné en rağab 782/octobre 1380 à Alexandrie

(Ibn Duqmāq, al-Ğawhar, 447; al-Nafha, 228; al-Maqrīz̄̄, al-Sulūk, vol. V, 50; ibn Hağar al- Asqalān̄̄, Inbā', vol. I, 171; ibn Tag̉rībirdī, al-Nuğ̄um, vol. XI, 204; alDalīl, vol. I, 189, n 660; Hiba Yūsuf, « Le chef de la ronde », JAAUTH, vol. VIII/2, $\left.91, \mathrm{n}^{\circ} 23\right)$

\section{8-Maḥmūd ibn Muḥammad ibn Dāwūd, Ğamāl al-Dīn, al-Qaīṣarī al-Rūmī al- 'A ğamī, dit Abū'l-Tanā;}

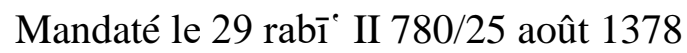

Révoqué à une date indeterminée

Mort le 2 rabī $^{-}$II 799/3 janvier 1397

(Cf. Ibn Duqmāq, al-Nafḥa, 290, n 115; al-Maqrīzī, al-Sulūk, vol. V, 50; ibn Hağar al- 'Asqalānī, al-Durar al-kāmina, vol. IV, 335; Inbā', vol. I, 541, n 54; ibn Qāḍ̄ Šuhba, Tārīh, vol. I, 645-646; ibn Tag̉rībirdī, al-Nuğ̄um, vol. XII, 158; al-Șairafī, Nuzhat al-nufūs, vol. I, 450-451, n 266; al-Sahāwī, Wă̌̆iz, vol. I, 325, n 727; alSuyūṭ̂̄, Husn, vol. II, 185; 'Abd al-Bāsit ibn Šāhīn al-Z̄āhirī, Nail, vol. II, 376, n 918; ibn Iyās, Badā' 'i', vol. I/2, 486; ibn al- Imād al-Hanbalī, Šadarāt, vol. VIII, 617; Aḥmad 'Abd al-Rāziq, «La hịsba », AnIsl, vol. XIII, 143, nºs 24, 26, 28, 30; Aḥmad 'Isa, al-Bimāristānāt, 126, n 3 ) 


\section{9- 'Uțmān ibn Sulaimān ibn Rasūl ibn Halīl ibn Nūḥ, Šaraf al-Dīn, al- Makarādīîn al-Hạafī dit al-Ašqar;}

Né en $741 / 1340$

Nommé à une date indeterminée

Mort en fonction le 14 rabī $^{\circ}$ II 791/12 avril 1389 à l'âge de 50 ans à Ġaza

Père de Muhib al-Dīn Muhammad ibn al-Ašqar ( $\left.n^{\circ} 73\right)$

(Cf. Ibn Hağar al- Asqalānī, al-Durar al-kāmina, vol. II, 440, n² 2580; ibn Tağrībirdī,

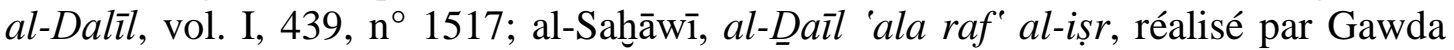
Hilāl et Muḥammad Maḥmūd Șubḥ, Le Caire, sd, 267)

\section{0- Quradamurdāš ibn ‘Abd Allah, Saif al-Dīn, al-Aḥmadī al-Yalbuġāwī;}

Nommé en ğumāda I 791/mai 1389

Révoqué en ğumāda II 791/juin 1389

Assassiné en du'l-ḥiğğa 794/novembre 1392 par ordre du sultan al-Ẓāhir Barqūq

(Cf. Al-Maqrīzī, al-Sulūk, vol. V, 224-225; ibn Ḥağar al-'Asqalān̄̄, al-Durar alkāmina, vol. III, 245, n 623; ibn Taġrībirdī, al-Nuğūm, vol. XII, 134; al-Dalīl, vol. II, 538, n 1848; al-Ṣairafì, Nuzhat al-nufūs, vol. I, 201, 226; al-Ṭabāh al-Halabī, I'lām al-nubalā', vol. II, 383)

\section{1-Yalbug̣ā ibn 'Abd Allah, Saif al-Dīn, al-Nāṣirī;}

Nommé en ğumāda II 791/juin 1389

Révoqué à une date indeterminée

Mort le 2 ramaḍān 817/15 novembre 1414

(Cf. Al-Maqrīzī, al-Sulūk, vol. VI, 364; al- 'Ain̄̄, al-Saif al-muhanad fì sirat al-malik al-Mu'ayyad, réalisé par Muhammad Fahīm Šaltūt, Le Caire, 1967, 328; ibn Ḥağar al'Asqalānī, Inbā', vol. III, 51, n 19; Ibn Tag̉rībirdī, al-Nuğ̄um, vol. XIV, 130; alManhal, vol. XII, 171-172, $\mathrm{n}^{\circ}$ 2684; al-Dalīl, vol. II, 794, $\mathrm{n}^{\circ}$ 2674; al-Ṣairafì, Nuzhat al-nufūs, vol. II, 346, n 528; al-Sahāwī, al-Ḍaw', vol. X, 290-291, n 1139; 'Abd alBāsiṭ ibn Šāhīn al-Ẓāhirī, Nail, vol. III, 271, n 1344; ibn Iyās, Badā' 'í, vol. II, 15)

\section{2- Tumāntamur ibn 'Abd Allah al-Ašrafi Ša 'bān ibn Ḥussaīn;}

Nommé le 8 šawwāl 791/30 septembre 1389

Révoqué en șafar 792/janvier 1390

Mort en $792 / 1390$ à Bahnasā

(Cf. Al- Maqrīzī, al-Sulūk, vol. V, 255; ibn Tağnībirdī, al-Nuğūm, vol. XI, 351; alManhal, vol. IV, 87, n 776; al-Dalīl, vol. I, 221, n 774; al-Ṣairafī, Nuzhat al-nufūs, vol. I, 254, 319; Gaston Wiet, Les biographies, 111, n 766; Hiba Yūsuf, « Le chef de la ronde », JAAUTH, vol. VIII/ 2, 92, n 30)

36 - D’après le nom d’une tribu turque. Ibn Tagriībirdī, al-Dalīl, vol. I, 439, nº 1517. 


\section{3- Alī ibn ibn Sa d al-Dīn ibn ‘Abd Allah ibn Muḥammad, ‘Alā' al-Dīn, al- Tablāwī;}

Nommé le 14 rağab 792/28 juin 1390

Révoqué à une date indeterminée

Assassiné le 12 ramaḍān 803/26 avril 1401 à Ġaza

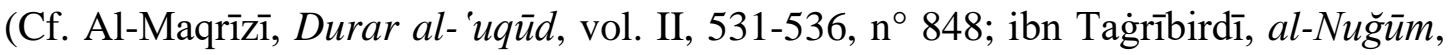
vol. XII, 79; al-Manhal, vol. VIII, 93-97, $\mathrm{n}^{\circ}$ 1600; al-Dalīl, vol. I, 459, n 1593; alSairafī, Nuzhat al-nufūs, vol. I, 306, 432, n 57; al-Sahāwī, al-Ḍaw', vol. V, 252-253, $\mathrm{n}^{\circ} 846$; Wă̆ğz, vol. I, 359, n 800)

\section{4- Kamšbuġā, Saif al-Dīn, al-Ḥamawī al-Yalbuḡāwī;}

Né en $741 / 1340$

Nommé le 19 ğumāda I 794/13 avril 1392

Révoqué le 18 šawwāl 794/7 septembre 1392

Empoisonné le 30 ramaḍān 801/5 juin 1399 à l'âge de 60 ans dans la prison d'Alexandrie

(Cf. Al-Maqrīzī, al-Sulūk, vol. V, 323; al-Muqaffa, vol. V, 7-8, n 1563; Durar al'uqūd, vol. III, 24-25, n 911; ibn Hağar al- Asqalānī, Inbā', vol. II, 81; ibn Tag̉rībirdī, al-Nuğūm, vol. XIII, 9; al-Manhal, vol. IX, 142-146, n 1927; al-Dalìl, vol. II, 560, n 1920; al-Șairafî, Nuzhat al-nufüs, vol. I, 345, 348; vol. II, 26-27, n $^{\circ}$ 301; al-Sahāwī, al-Daw', vol. VI, 230-231, n 793; Wağ̄iz, vol. I, 302; al-Ṭabāh alHalabī, I'lām al-nubalā', vol. II, 381-382; ibn Hațīb al-Nāṣirīya, al-Durr almuntahab, vol. IV, 1924-1927, n 1137; Gaston Wiet, Les biographies, 285, n 1914)

\section{5- Al-Šarīf Faḩr al-Dīn;}

Nommé le 19 šawwāl 794/8 septembre 1392

Révoqué à une date indeterminée

Mort à une date indeterminée

(Cf. Al-Maqrīzī, al-Sulūk, vol. V, 326; al-Șairafī, Nuzhat al-nufūs, vol. I, 348)

\section{6- Muḥammad ibn Ibrāhīm ibn Aḥmad, Šams al-Dīn, al-Ṣūfī;}

Né en $742 / 1341$

Nommé sous le règne du sultan al-Ẓāhir Barqūq

Révoqué à une date indeterminée

Mort le 13 muharram 832/23 octobre 1428 à 81 ans

(Cf. Al-Maqrīz̄i, al-Sulūk, vol. VII, 197-198; ibn Tağrībirdī, al-Nuğūm, vol. XV, 154. Al-Ṣairafī avait souligné qu'il avait 83 ans lors de sa mort. Nuzhat al-nufūs, vol. III, $\left.170, \mathrm{n}^{\circ} 664\right)$ 
47- Alī ibn Sa d al-Dīn ibn 'Abd Allah ibn Muḥammad, 'Alā' al-Dīn, al-Ṭablāwī;

Renommé le 24 dū'l-hịğğa 798/28 septembre 1396

Révoqué le 14 ša 'bān 800/2 mai 1398

(Cf. Al-Maqrīzī, al-Sulūk, vol. V, 292, 388, Durar al-'uqūd, vol. II, 531-536, n 848; Ibn Hağar al- 'Asqalān̄i, Inbā', vol. II, 172-173, n 72; ibn Qāḍ̄ Šuhba, Tārīh̆, vol. III, 590, 656; ibn Tağrībirdī, al-Nuğùm, vol. XII, 79; al-Manhal, vol. VIII, 93-97, $\mathrm{n}^{\circ}$ 1600; al-Dalīl, vol. I, 459, n 1593; al-Șairafì, Nuzhat al-nufūs, vol. I, 432, n 57, vol. II, 7-8; al-Sahāwī, al-Ḍaw', vol. V, 252-253, n 846; Wağ̄z, vol. I, 359, n 800; 'Abd al-Bāsit ibn Š̄āhīn al-Ẓāhirī, Nail, vol. II, 392; ibn Iyās, Badā'ie, vol. I/2, 498, 584; Gaston Wiet, Les biographies, 232, n 1588; Aḥmad 'Isa, al-Bimāristānāt, 126, 127 , $\mathrm{n}^{\circ}$ 4; Aḥmad 'Abd al-Rāziq, Šurțat al-qāhira zaman salāțin al-mamālīk, Le Caire, $\left.1982,85, \mathrm{n}^{\circ} 57\right)$

\section{8- Aitumuš ${ }^{37}$ ibn 'Abd Allah, al-Asundumurī al-Bağāsī al-Ğirğāwī;}

Né en $742 / 1341$

Nommé le 14 ša bān 800/2 mai 1398

Révoqué en rabī' I 802/novembre 1399

Assassiné en 15 ša bān 802/11 avril 1400 à Damas à 60 ans

(Cf. Ibn Qāḍ̄ Šuhba, Tārīh, vol. III, 656; Ibn Hağar al- Asqalān̄i, Inbā', vol. II, 118,

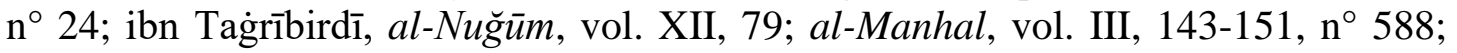
al-Dalīl, vol. I, 164, n 587; al-Șairafì, Nuzhat al-nufūs, vol. I, 463; vol. II, 7-8; alSahāwī, al-Ḍaw', vol. II, 324, n 1959; 'Abd al-Bāsit ibn Šāhīn al-Ẓāhirī, Nail, vol. II, 392; ibn Iyās, Badā 'i', vol. I/2, 498; ibn Haț̣̂̄b al-Nāșirīya, al-Durr al-muntahab, vol. II, 645-646, n 353; Gaston Wiet, Les biographies, 84, $\mathrm{n}^{\circ} 581$ )

\section{9-Baibars ${ }^{38}$ ibn 'Abdallah, al-Ẓāhirī al-Dawādār;}

Nommé le 14 ğumāda I 802/12 janvier 1400

Révoqué le 6 ğumāda II 808/3 février 1400 puis arrêté et emprisonné à Alexandrie Assassiné en 811/1408 dans la prison d'Alexandrie

(Ibn Hağar al- 'Asqalānī, Inbā', vol. II, 322, 323, 405, n 5; ibn Tag̉rībirdī, al-Manhal, vol. III, 481-483, n 726; al-Dalīl, vol. I, 205-206, n 724; al-Șairafī, Nuzhat al-nufūs, vol. II, 45; ibn Iyās, Badā' 'i', vol. I/2, 564)

\section{0- Yašbak ibn 'Abd Allah, Saif al-Dīn, al-Ša 'oān̄̄ al-Z̄āhirī Barqūq;}

Nommé le 21 ğumāda II 808/18 février 1400

\footnotetext{
37. Aitumuš signifie «il a fait » ou " dit, parlé». J. Sauvaget, « Noms », vol. CCXXXVIII, 39, n 38.

38- Baibars est un nom composé de deux syllabes : "Bai » signifie prince et «bars» signifie tigre alors Baibars signifie prince- tigre. J. Sauvaget, "Noms », JA, vol. CCXXXVIII, 43, n 65. Selon David Ayalon Bay signifie heureux. « Names », IOS, 201.
} 
Révoqué en ğumāda I 810/octobre 1407

Assassiné le 13 rabīi II 810/17 septembre 1707 à Ba'albak

(Cf. Al-Maqrīzī, al-Sulūk, vol. VI, 151; ibn Hağar al- 'Asqalānī, Inbā', vol. II, 323, 383-384; ibn Tağrībirdī, al-Nuğūm, vol. XIII, 170; XIV, 117; al-Manhal, vol. XII, 119-122 n 1256; al-Dalīl, vol. II, 784, n 2646; al-Ṣairafī, Nuzhat al-nufūs, vol. II, 216, 241, 242; al-Saḩāwī, al-Ḍaw', vol. X, 278-279, n 1090; 'Abd al-Bāsit ibn Šāhīn al-Zāhirī, Nail, vol. III, 157, n' 1176; ibn Iyās, Badā' ' ', vol. I/2, 783; Gaston Wiet, Les biographies, 399, n 2651; Rania Ossama, Les trésoriers, 393-394, n 44)

\section{1- Tağrībirdī ${ }^{39}$ ibn 'Abd Allah al-Bašbuġāwī;}

Nommé le 3 ğumāda I 810/6 octobre 1407

Révoqué en 813/1410

Mort le 16 muḥarram 815/27 avril 1412 à Damas après une grave maladie

(Cf. Ibn Hağar al- 'Asqalān̄̄, Inbā', vol. II, 383, 527, nº 9; vol. III, 7; ibn Tağrībirdī, al-Nuğüm, vol. XIV,115, 117, 118; al-Manhal, vol. IV, 31-43, n 760; al-Dalìl, vol. I, 215-216, n 758; al-Ṣairafì, Nuzhat al-nufūs, vol. II, 241; al-Sahāwī, al-Ḍaw', vol. III, 27, n' 132; ibn Iyās, Badā 'í', vol. I/2, 809, 818; ibn al- 'Imād al-Hanbalī, Šadarāt, vol. IX, 164)

\section{2-Muḥammad ibn Aḥmad ibn 'Abd al-Malik, Šams al-Dīn, al-Daimairī al- Mālikī;}

Nommé à une date indeterminée

Révoqué à une date indeterminée

Mort le 29 ramaḍan 813/25 janvier 1411

(Cf. Al-Maqrīzī, al-Sulūk, vol. VI, 283; al-Șairafî, Nuzhat al-nufūs, vol. II, 279, n 484; al-Sahāwī, al-Daw', vol. VI, 329, n 1076; Gaston Wiet, Les biographies, 303, n 2031; Aḥmad 'Abd al-Rāziq, «La ḥisba », AnIsl, vol. XIII; 143-144, n 23, 27; Aḥmad 'Isa, al-Bimāristanāt, 127, n 5.

Ibn Tag̉rībirdī avait mentionné sa mort en 9 ramaḍān 813/5 janvier 1411. Al-Dalīl, vol. II, 592, $\mathrm{n}^{\circ}$ 2033.)

Père de Zain al-Dīn Muḥammad al-Daimairī ( $\mathrm{n}^{\circ}$ 55) et grand-père de Badr al-Dīn Muḥammad al-Daimairī ( $\mathrm{n}^{\circ}$ 72/a)

\section{3-Tamurtāšs ${ }^{40}$ al-Muḥamadī al-Ẓāhirī;}

Nommé en muḥarram 814/mai 1411

Révoqué à une date indeterminée

Étranglé dans la prison d'Alexandrie le 18 muharram 818/mars 1415

\footnotetext{
39 Ibn Tağrībirdī signifie le don de Dieu. Al-Dalīl, vol. I, 215, nº 758.

40. Ibn Ḥağar al-'Asqalānī lui donna le nom de Damurdāš. Inbā', vol. III, 79-80, nº 8.
} 
(Cf. Al-Maqrīzī, al-Sulūk, vol. VI, 287; ibn Hağar al- 'Asqalānī, Inbā', vol. II, 480, 481, 514; vol. III, 79-80, n 8; ibn Tag̉īibird̄̄, al-Nuğ̄um, vol. XIII, 120; vol. XIV, 26; ibn Iyās, Badā' 'i , vol. II, 18, 19)

\section{4- Ṣalāḥ al-Dīn ibn Badr al-Dīn;}

Mandaté par Tamurtāš le 24 muḥarram 814/18 mai 1411

Révoqué à une date indeterminée

Mort à une date indeterminée

(Cf. Ibn Hağar al- 'Asqalānī, Inbā', vol. II, 480)

\section{5- Muḥammad ibn Muḥamamd ibn 'Abd al-Malik, Zaīn al-Dīn, al-Daimairī;}

Né en 783/1381

Mandaté à une date indeterminée

Révoqué à une date indeterminée

Mort le 3 ša bān 833/27 avril 1430 à l'âge de 50 ans

Fils de Šams al-Dīn Muḥammad al-Daimairī ( ${ }^{\circ}$ 52) et père de Badr al-Dīn Muḥammad al-Daimairī ( $\mathrm{n}^{\circ}$ 72/a)

(Cf. Al-Maqrīzī, al-Sulūk, vol. VII, 222; ibn Hağar al- 'Asqalān̄̄, Inbāa', vol. III, 451; vol. IV, 207, $\mathrm{n}^{\circ}$ 13; ibn Tağrībird̄̄, al-Nuğūm, vol. XV, 168; al-Ṣairafī, Nuzhat alnufüs, vol. III, 214, n' 706; al-Sahāwī, al-Daw', vol. IX, 23, 24, n 68; ibn Iyās, Badā'i', vol. II, 133; Aḥmad 'Abd al-Rāziq, «La ḥisba », AnIsl, vol. XIII, 160-161, n os $103,105,109)$

Fils de Šams al-Dīn Muhammad al-Daimairī $\left(n^{\circ}\right.$ 52) et père de Badr al-Dīn Muḥammad al-Daimairī ( $\mathrm{n}^{\circ}$ 72/a)

\section{6- Fatḥ Allah ibn Musta șim ibn Nafīs al-Dīn, Fatḥ al-Dīn, al-Tabrīzī;}

Né en $759 / 1358$

Nommé en muḥarram 814/mai 1411

Révoqué en rabīe II 815/juillet 1412

Étranglé le 5 rabīe I 816/5 juin 1413 à l'âge de 57 ans

(Cf. Al-Maqrīzī, al-Sulūk, vol. VI, 288; Durar al- 'uqūd, vol. III, 8-17, n 899; ibn Hağar al-'Asqalānī, Inbā', vol. III, 29, n 24; ibn Tağrībird̄̄, al-Nuğ̄um, vol. XIII, 205; al-Dalīl, vol. II, 519, n 1792; al-Sahāwī, al-Ḍaw', vol. VI, 165-166, n 556; ibn Iyās, Badā'i', vol. II, 6; Ibn al-'Imād al-Hanbalī, Šadarāt, vol. IX, 180; ibn Huațīb alNāșirīya, al-Durr al-muntahab, vol. IV, 1867, n 1097)

\section{7- Aḥmad ibn Abī Aḥmad, Šihāb al-Dīn, al-Ṣafadī;}

Nommé le 22 rabīe II 815/1 ${ }^{\text {er }}$ août 1412

Mort en fonction le 12 rabī $^{e}$ I 819/29 avril 1417 
(Cf. Ibn Tağrībirdī, al-Nuğūm, vol. XIII, 205; XIV, 142)

Al-Maqrīzī avait indiqué sa mort en 820/1417. Al-Sulūk, vol. VI, 364, 424; al-Șairafī, Nuzhat al-nufūs, vol. II, 376, n 546; al-Sahāwī, al-Daw', vol. I, 225-226; ibn al'Imād al-Hanbalī, Ša darāt, vol. IX, 180.

Ibn Ḥăgar al- 'Asqalān̄̄ avait souligné sa nomination en 11 rab̄̄e 815/21 juillet 1412 et qu'il a essayé en vain de refuser. Inbä', vol. II, 514; vol. III, 103, $\mathrm{n}^{\circ} 1$ )

\section{8- Yaḥīya ibn Mụ̣ammad ibn Yūsuf Šams al-Dīn, Taqī al-Dīn, al-Karmānī al- Bà̉dādī;}

Né en 762/1361

Nommé en rabīe I 819/mai 1416

Révoqué à une date indeterminée

Mort le 18 ğumāda II 833/14 mars 1430 à l'âge de 71 ans affecté par l'épidémie de peste

(Cf. Al-Maqrīzī, al-Sulūk, vol. VII, 219; ibn Tag̉rībird̄̄, al-Nuğ̄um, vol. XV, 169; alManhal, vol. XII, 105, $\mathrm{n}^{\circ}$ 2647; al-Dalīl, vol. II, 781, $\mathrm{n}^{\circ}$ 2637; al-Ṣairafī, Nuzhat alnufūs, vol. III, 210, n 693; al-Sahāw, al-Ḍaw', vol. X, 259-261, n 1040; ibn Iyās, Badā' 'i', vol. II, 131; ibn al- 'Imād al-Hanbalī, Ša darāt, vol. IX, 300; Ismā īl al-Bābān̄̄ al-Buğdādī, Hadīyat al- 'ārifìnn asmā' al-mū'alifìnn wa ațār al-mușanīfìnn min kašf al-žunūn, photocopie de la copie originale d'Istanbūl, 1951, vol. II, 466, $\mathrm{n}^{\circ} 8559$ )

\section{9- Al-Ṭanbuġā ibn ‘Abd Allah, Saif al-Dīn, al-Qirmšĩ al-Ẓāhirī Barqūq;}

Nommé à une date indeterminée

Révoqué en 823/1420

Assassiné dans la citadelle de Damas le 15 ğumāda I 824/18 mai 1421

(Cf. Al-Maqrīzī, al-Sulūk, vol. VII, 16, 49; ibn Hağar al-'Asqalān̄̄, Inbā', vol. III, 255-256, n 4; ibn Tağrībirdī, al-Nuğūm, vol. XIV, 100, 189-191; al-Manhal, vol. III, 62-66, n 537; al-Dalīl, vol. I, 151, n 536; al-Șairafī, Nuzhat al-nufūs, vol. II, 522; al-Sahāwī, al-Daw', vol. II, 319, n 1025; ibn Hațīb al-Nāṣirīya, al-Durr almuntahab, vol. II, 633-634, n 343; Gaston Wiet, Les biographies, 77, $\mathrm{n}^{\circ}$ 531)

\section{0- Alī, Nūr al-Dīn, al-Safṭī;}

Né en $782 / 1380$

Nommé à une date indeterminée

Révoqué à une date indeterminée

Mort en ğumāda II 832/mars 1429 à l'âge de 50 ans

(Cf. Ibn Hağar al- 'Asqalānī, Inbā', vol. III, 428, n 14; al-Ṣairafì, Nuzhat al-nufūs, vol. III, 173, n 670; al-Sahāwīi, al-Daw', vol. VI, 58, n 175) 


\section{1- Ğānībak ${ }^{41}$ ibn `Abd Allah, Saif al-Dīn, al-Ṣūfī al-Ẓāhirī Barqūq;}

Nommé le 16 šawwāl 824/14 octobre 1421

Arrêté et emprisonné à Alexandrie en dū'l-hịğğga 824/décembre 1421

Assassiné en 841/1438 à Dīyār Bakr

(Cf. Al-Maqrīzī, al-Sulūk, vol. VII, 344; Ibn Hağar al- Asqalānī, Inbā', vol. IV, 80, n 13; ibn Tağrībirdī, al-Nuğùm, vol. XV, 212-213; al-Manhal, vol. IV, 224-230, n 819; al-Dalīl, vol. I, 236, n 817; al-Șaīrafī, Nuzhat al-nufūs, vol. II, 510; vol. III, 430, n $^{\circ}$ 777; al-Sahāwī, al-Daw', vol. III, 57, n 230; ibn Iyās, Badā' 'i', vol. II, 76, 178; Gaston Wiet, Les biographies, 118, $\mathrm{n}^{\circ} 808$ )

62-Muḥammad ibn 'Alī b. Muḥamamd ibn 'Alī ibn 'Uțmān, Šams al-Dīn, alBadrašī al-Qāhirī al-Šāf' 'ī; Mandaté au temps de Ğānībak al-Ṣūfī

Né en 788/1386

Révoqué à une date indeterminée

Mort le 7 šawwāl 846/8 février 1443 à l'âge de 58 ans

(Cf. Ibn Hağar al- 'Asqalān̄̄, Inbā', vol. IV, 206; al-Sahāwī, al-Daw', vol. IX, 20; alTibr, vol. I, 147-148; ibn al-'Imād al-Ḥanbalī, Ša darāt, vol. IX, 378; Aḥmad 'Isa, alBimāristānāt, 125-126, $\mathrm{n}^{\circ}$ 2)

\section{3- Ṭarābāy, Saif al-Dīn, al-Ẓāhirī Barqūq;}

Né en $778 / 1376$

Nommé le 6 dū'l-ḥiğğa 824/2 décembre 1421

Arrêté et emprisonné dans la prison d'Alexandrie le $1{ }^{\text {er }}$ rabī $^{\circledR}$ II 825/25 mars 1422

Mort à Tripoli le 4 rağab 838/ 3 février 1435 à 60 ans

(Cf. Ibn Taġrībirdī, al-Manhal, vol. III, 491; vol. VI, 373-377, n 1235; al-Dalīl, vol. I, 359-360, $\mathrm{n}^{\circ}$ 1232; al-Ṣairafī, Nuzhat al-nufūs, vol. III, 324, n 742; Gaston Wiet, Les biographies, $175, \mathrm{n}^{\circ} 1224$.

Ibn Hağar al-'Asqalānī avait signalé son arrestation en rabī' II 824/avril 1421. Inbā', vol. III, 250, 267, 558.

Tandis que ibn Iyās l'avait soulignée arrestation en rabī' I 825/mars 1422. Badā'i', vol. II, 78-79. Al-Sahāwī avait mentionné sa mort en rağab 837/février 1434. AlDaw', vol. IV, 7, $\left.\mathrm{n}^{\circ} 19\right)$

\section{4- Baībuğă $\bar{a}^{42}$ ibn ‘Abd Allah, Saif al-Dīn, al-Muẓaffarī al-Ẓāhirī Barqūq ;}

Né en $773 / 1372$

Nommé le 16 rabīe II 825/9 avril 1422

\footnotetext{
41. Ğānībak est un mot turc signifiant « prince-âme » il se compose de deux syllabes: Ğān qui signifie âme et bak qui signifie prince. J. Sauvaget, "Noms ", JA, vol. CCXXXVIII, 46, $\mathrm{n}^{\circ} 84$.

42. Ibn Ḥağar al-'Asqalānī lui donna le nom de Baibuġā. Inbā', vol. III, 445, n 15.
} 
Arrêté et emprisonné le 29 šawwāl 827/24 septembre 1424

Mort le 6 ğumāda II 833/31 mars 1430 à l'âge de 60 ans affecté par l'épidémie de peste

(Cf. Al-Maqrīzī, al-Sulūk, vol. VII, 218; ibn Hağar al-'Asqalān̄̄, Inbā', vol. III, 270, 329, 445, n 15; al-Șairafī, Nuzhat al-nufūs, vol. III, 7, 207, n 681; al-Sahāwī, alDaw', vol. III, 22, n 106; al-Tibr, vol. I, 151; ibn Iyās, Badā' 'i', vol. II, 82, 93, 129; Gaston Wiet, Les biographies, 105, $\mathrm{n}^{\circ} 723$.

Ibn Tağrībirdī avait mentionné qu'il fut poignardé. Al-Nuğūm, vol. XIV, 247, 269; alManhal, vol. III, 489-492, ${ }^{\circ} 732$; al-Dalīl, vol. I, 207, $\mathrm{n}^{\circ} 730$ )

\section{5- Quğuq, Saif al-Dīn, al-Ša bānī al-Ẓāhirī Barqūq, al- Isāw;}

Nommé le 29 šawwāl 827/24 septembre 1424

Mort en fonction le 9 ramaḍān 829/15 juillet 1426

(Cf. Ibn Hağar al- Asqalānī, Inbā', vol. III, 380, n 10; ibn Tağrībirdī, al-Manhal, vol. IX, 35, n 1841; al-Dalīl, vol. II, 535, n 1833; al-Ṣairafì, Nuzhat al-nufūs, vol. III, 98, 111-112, n 646; al-Sahāwī, al-Ḍaw', vol. VI, 212, n 702; ibn Iyās, Badā 'i', vol. II, 93, 107)

\section{6- Yašbak ibn 'Abd Allah, Saif al-Dīn, al-Sāqī al-Ẓāhirī Barqūq, dit al-A 'rağ;}

Nommé le 26 ramaḍān 829/31 juillet 1426

Mort en fonction le 3 ğumāda II 831/20 mars 1428

(Cf. Al-Maqrīzī, Durar al- 'uqūd, vol. III, 534-535, n 1440; ibn Hağar al- Asqalānī, Inb $\bar{a}^{\prime}$, vol. III, 417, n 21; Ibn Tag̉rībirdī, al-Nuğūm, vol. XIII, 170; al-Manhal, vol. XII, 122-126, $\mathrm{n}^{\circ}$ 2657; al-Dalīl, vol. II, 784-785, $\mathrm{n}^{\circ}$ 2647; al-Șairafì, Nuzhat alnufūs, vol. III, 104, 140-141, n 661; al-Sahāw̄i, al-Daw', vol. IX, 276-277, n 1088; 'Abd al-Bāsit ibn Šāhīn al-Ẓāhirī, Naīl, vol. IV, 233, n 1652; ibn Iyās, Badā'i', vol. II/ 107, 119)

\section{7- Ğarqaṭlū ${ }^{43}$ ibn 'Abd Allah, Saif al-Dīn, al-Ẓāhirī Barqūq;}

Né en $767 / 1366$

Nommé le 8 ğumāda II 831/25 mars 1428

Révoqué le 20 rağab 835/23 mars 1432

Mort le 19 rağab 837/1 er mars 1434 à Damas à l'âge de 70 ans

(Cf. Al-Maqrīz̄ì, al-Sulūk, vol. VII, 175; ibn Hağar al- 'Asqalān̄̄, Inbā', vol. III, 473; 523-524, n 7; ibn Tağrībirdī, al-Nuğūm, vol. XV, 221; al-Manhal, vol. IV, 212-215, n 812; al-Dalīl, vol. I, 234, n 810; al-Sahāwī, al-Ḍaw', vol. III, 51, n 198; 'Abd alBāsit ibn Šāhīn al-Z̄āhirī, Naīl, vol. IV, 233; ibn Iyās, Badā' 'i', vol. II, 119, 141; ibn

\footnotetext{
43. Ce nom se compose de deux syllables: le premier Ğar est un mot persan qui signifie quatre tandis que quțlū est turc qui signifie béni. Ibn Taġrībirdī, al-Manhal, vol. IV, 215, n 812.
} 
Hatịīb al-Nāṣirīya, al-Durr al-muntahab, vol. II, 819-820, n 441; Gaston Wiet, Les biographies, $117, \mathrm{n}^{\circ} 801$.

Al-Ṣairafī avait signalé sa nomination le 5 ğumāda II 831/22 mars 1428. Nuzhat alnufüs, vol. III, 294, $\mathrm{n}^{\circ}$ 736)

\section{8- Sūdūn ibn 'Abd Allah, Saif al-Dīn, min ‘Abd al-Raḥman;}

Nommé le 22 rağab 835/25 mars 1432

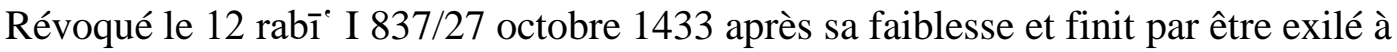
Damiette

Mort le 20 muharram 841/24 juillet 1437 à Damiette

(Cf. Al-Maqrīz̄i, al-Sulūk, vol. VII, 262, 263; ibn Hağar al- 'Asqalān̄̄, Inbā', vol. III, 473, 481, 513; vol. IV, 81, n 15; ilbn Taġrībirdī, al-Nuğūm, vol. XV, 221; alManhal, vol. VI, 152-156, $\mathrm{n}^{\circ}$ 1144; al-Dalīl, vol. I, 332, n 114; al-Șairafî, Nuzhat alnufüs, vol. III, 233, 275.

Al-Sahāwī et Ibn Iyās avaient souligné sa mort en dūu'l-ḥiğğa 841/juin 1438. Al-Ḍaw', vol. III, 275-276, $\mathrm{n}^{\circ}$ 1048; Badā' $i$, vol. II, 141, 152, 192, 193; Gaston Wiet, Les biographies, $162, \mathrm{n}^{\circ} 1133$ )

\section{9- Ğawhar ${ }^{44}$ ibn 'Abd Allah, Șafī al-Dīn, al-Qunqubā'ī al-Hูāzindār;}

Né en $774 / 1373$

Nommé le 13 rabīe II 837/28 octobre 1433

Révoqué en rağab 837/février 1434

Mort le $1^{\text {er }}$ ša bān 844/26 décembre 1440 à l'âge 70 ans

(Cf. Al-Maqrīzī, al-Sulūk, vol. VII, 263; ibn Hağar al- 'Asqalānī, Inbā', vol. IV, 167169, n 8; Ibn Tağrībirdī, al-Manhal, vol. V, 38-42, n 872; al-Dalīl, vol. I, 254, n 870; al-Șairafī, Nuzhat al-nufūs, vol. III, 277; al-Sahāwī, al-Ḍaw’, vol. III, 82, n 327; ibn Iyās avait signalé qu'il mourut à l'âge de 80 ans. Badā 'í, vol. II, 153, 227; Rania Ossama, Les trésoriers, 407, $\mathrm{n}^{\circ}$ 64)

\section{0- Ināl ${ }^{45}$, Saif al-Dīn, al-Ğakamī;}

Nommé le 7 ša bān 837/mars 1434

Révoqué le 8 rabī I 839/1 ${ }^{\text {er }}$ octobre 1435

Assassiné le 22 dū'l-qi da 842/6 mai 1439 à Damas

(Cf. Al-Maqrīzì, al-Sulūk, vol. VII, 266; ibn Taġrībirdī, al-Nuğūm, vol. XV, 40-41, 469; al-Manhal, vol. III, 196-200, n 617; al-Dalīl, vol. I, 172, n 616; al-Ṣaīrafì, Nuzhat al-nufūs, vol. III, 283, 332; al-Sahāwī, al-Daw', vol. II, 327, n 1074; ibn

\footnotetext{
44- Le nom Ğawhar compte parmi les noms arabes les plus fréquents donnés aux eunuques à l'époque mamelouke. David Ayalon, The Eunuchs, 275.

45 -Le nom Ināl signifie rayon de la lune. Ibn Tagirībirdī, al-Manhal, vol. III, 194.
} 
Iyās, Badā' 'i , vol. II, 154, 166, 215; ibn Hațî̉b al-Nāșirīya, al-Durr al-Muntahab, vol. II, 651-652, n 360; Gaston Wiet, Les biographies, 88, n 610)

\section{1- ‘Alī b. Muflị̣, Nūr al-Dīn, al-Ḥanafī;}

Né en $771 / 1370$

Nommé à une date indeterminée

Mort en fonction le 22 dū'l-qi da 841/17 mai 1438 à l'âge de 70 ans

(Cf. Ibn Ḥağar al- 'Asqalānī, Inbā', vol. IV, 83, n 23)

Ibn Tağrībirdī avait signalé sa mort en 12 dū'l-qi da 841/7 mai 1438. Al-Nŭ̌ùm, vol. XV, 220; al-Dalīl, vol. I, 485, n 1684; al-Sahāwī, al-Daw', vol. VI, 39-40, n 115; Aḥmad 'Isa, al-Bimāristānāt, 127, n 6)

72/a- Muḥammad ibn Mụ̣ammad ibn Muḥammad ibn, Badr al-Dīn ibn Zain alDīn al-Daimairī, al-Mālikī;

Né en 796/1394

Nommé à une date indeterminée

Révoqué à une date indeterminée

Mort en ramaḍān 846/janvier 1443 avant d'accomplir 50 ans

Fils de Zain al-Dīn Muḥammad al-Daimairī ( $\left.n^{\circ} 55\right)$ et petit-fils de Šams al-Dīn Muḥammad al-Daimairī ( $n^{\circ}$ 52)

(Cf. Ibn Hağar al- 'Asqalān̄̄, Inbā', vol. IV, 207, n 13; al-Sahāwī, al-Tibr, vol. I, 151; Aḥmad 'Isa, al-Bimāristānāt, 127, n 7)

72/b- Muḥammad ibn Muḥammad ibn Badīr, Badr al-Dīn, al- Abbāssī, dit al 'Ağamī;

Nommé à une date indeterminée

Révoqué à une date indeterminée

Mort en šawwāl 846/février 1443

(Cf. Ibn Hağar al-'Asqalānī, Inbā', vol. IV, 207, n 14; al-Ṣaīrafī, Nuzhat al-nufūs, vol. III, 213, n 704; al-Sahāwī, al-Daw', vol. IX, 55 n 154; al-Tibr, vol. I, 149; Aḥmad 'Isa, al-Bimāristānāt, 127-128, n 8)

\section{3- Muḥammad ibn Šarf al-Dīn 'Uțmān ibn Rasūl ibn Nūḥ, Muḥib al-Dīn, al- Karādīit ${ }^{46}$ dit ibn al-Ašqar;}

Né en $773 / 1372$

Nommé le 3 rabī̄ II 842/23 septembre 1438

Révoqué en rabī̄ II 849/juillet 1445

46- D'après le nom d'une tribu turque. Ibn Tagrībirdī, al-Nuğūm, vol. XVI, 204, nº 4. 
Mort le 12 rağab 863/15 mai 1459 à l'âge de 90 ans

Fils de Šaraf al-Dīn 'Uțmān al-Ašqar (n 39)

(Cf. Ibn Hağar al- 'Asqalānī, Inbā', vol. IV, 96, 236; al-Daīl 'ala raf' al-'iṣr, 266-278; ibn Tağrībirdī, al-Nuğūm, vol. XVI, 204; Hawādit al-duhūr fì mada al-'ayām wa'lšuhūr, réalisé par Fahīm Muhammad Šaltūt, Le Caire, 1990, vol. I, 133; al-Manhal, vol. X, 185-186, n 2253; al-Dalīl, vol. II, 653, n 2245; al-Sahāwī, al-Daw', vol. VIII, 143-145, n 335; Wağı̆z, vol. II, 725, n 1665; Ğalāl al-Dīn Ibn 'Abd al-Raḥman

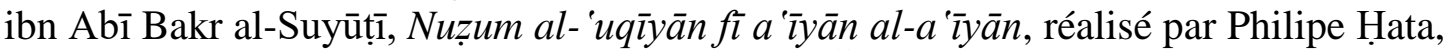
New York, 1927, 153, n 159; 'Abd al-Bāsit ibn Šāhīn al-Ẓāhirī, Nail, vol. VI, 58, nº 2464; ibn Iyās, Badā' 'í, vol. II, 250, 353)

\section{4- Muḥammad ibn Aḥmad ibn Yūsuf, walī al-Dīn, al-Safṭī;}

Né en 792/1390

Nommé le 2 rabīi II 849/8 juillet 1445

Révoqué en rabīe II 852/juin 1448

Mort en dِū'l hịğğa 854/janvier 1451 à l'âge de 62 ans

(Cf. Ibn Hağar al- Asqalānī, al-Dֵaīl, 245-256; al-Sahāwī, al-Tibr, vol. II, 70-73, nº 99; ibn Tağrībirdī, al-Nuğūm, vol. XV, 375; Hawādit, vol. I, 153; al-Suyūṭ̂, Nuzum al-'uqīyān, 139, n 134; ibn Iyās, Badā'i' ' vol. II, 250, 263, 287; Aḥmad 'Isa, alBimāristānāt, 128, $\mathrm{n}^{\circ}$ 9)

\section{5- Muḥammad ibn Ạ̣mad ibn Muḥammad, dit Abī al-Ḩair al-Naḥ̣̣ās;}

Né en $815 / 1412$

Nommé le 11 rabīi II 852/14 juin 1448

Révoqué le 2 ğumāda I 854/13 juin 1450

Mort le 20 muharram 864/16 novembre 1459 affecté par l'épidémie de peste à l'âge de 49 ans

(Cf. Ibn Hağar al- 'Asqalān̄̄, Raf' al-iṣr, 251; ibn Tag̉rībirdī, al-Nuğ̄um, vol. XV, 15, 382, 410, 413, 417; vol. XVI, 210-211; al-Dalīl, vol. II, 828, n 2785; al-Manhal, vol. XII, 322-325, n 2797; Hawādit, vol. I, 266; al-Sahāwī, al-Daw', vol. VII, 63-66, n 127; al-Tibr, vol. II, 77; Wağìz, vol. II, 734, n 1689; al-Dalīl, vol. II, 828, n 2785; 'Abd al-Bāsiṭ ibn Šāhīn al-Zāhirī, Nail, vol. VI, 70, n 2482; ibn Iyās, Badā' 'i', vol. II, 263, 280, 356)

\section{6- Mūsa ibn ‘Alī ibn Sulaimān, Šarf al-Dīn, al-Anșārī al-Tatā'î́ ${ }^{47}$, dit ibn al- Muhalața;}

Né en $821 / 1418$

Nommé le 2 ğumāda II 854/13 juin 1450

\footnotetext{
47- D'après le nom du village de Tatā dans le gouvernorat al-Munūfiya. 'Abd al-Bāsiț ibn Šāhīn al-Ẓāhirī, Nail, vol. VII, $160, n^{\circ} 4$.
} 
Révoqué en 857/1453

Mort en rabī' I 881/juillet 1476 à la Mecque à l'âge de 60 ans

(Cf. Ibn Taġrībirdī, al-Nuğūm, vol. XV, 417; Hawādit, vol. II, 508-509; al-Sahāwī, al-Daw', vol. X, 184-186, n 780; Wăğtz, vol. III, 878, n² 2007; 'Abd al-Bāsit ibn Šāhīn al-Zāhirīi, Nail, vol. VII, 160, n 3013; ibn Iyās, Badā' $i^{\prime}$, vol. II, 280; vol. III, 120; Aḥmad 'Isa, al-Bimāristānāt, 129, $\mathrm{n}^{\circ} 11$ )

\section{7- Mụ̣ammad ibn Ạ̣mad ibn Muḥammad ibn Yạ̣īya ibn Nāṣir al-Dīn ibn al- Mu izz ibn al-Muḥīyawī, dit ibn al-Muḩalața;}

Né en 790/1388

Nommé en 857/1453

Mort en fonction le 29 rabīi $^{\circ}$ II 858/28 avril 1454 à l'âge de 68 ans

(Ibn Tağrībirdī, al-Nuğūm, vol. XVI, 170-171; Hawādiț, vol. II, 508, 509; al-Saḩāwī, al-Daw', vol. X, 27 n 80; Wağ̄̌z, vol. II, 686, n 1576; 'Abd al-Bāsit ibn Šāhīn alZāhirī, Nail, vol. V, 417, n 2350; ibn Iyās, Badā' 'i', vol. II, 319)

\section{8- 'Abd al-Raḥman ibn 'Alī Nūr al-Dīn ‘Alī ibn Sirāğ al-Dīn, Ğalāl al-Dīn, ibn al-Mulaqin;}

Né en 790/1388

Nommé le $1^{\text {er }}$ gumāda I 858/30 avril 1454

Révoqué à une date indeterminée

Mort le 8 šawwāl 870/24 mai 1466 à l'âge de 80 ans

(Cf. Ibn Tağrībird̄̄, al-Nuğūm, vol. XVI, 348-349; al-Sahāwī, al-Ḍaw', vol. IV, 101-

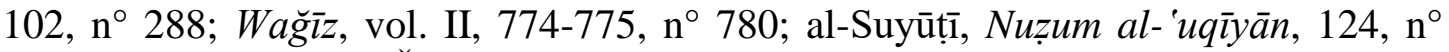
102; 'Abd al-Bāsit ibn Šāhīn al-Zāhirī, Nail, vol. VI, 241, n 2649; ibn Iyās, Badā' 'i', vol. II, 439; ibn al- 'Imād al-Hanbalī, Ša darāt, vol. VII, 310)

\section{9- Muḥammad ibn 'Alī ibn Muḥammad Qāsim al-Šams al-Qāhirī al-Bahā'̄̄, dit ibn al-Muraham ${ }^{48}$;}

Né en 808/1405

Nommé à une date indeterminée

Révoqué en șafar 867/novembre 1462

Mort le 14 ğumāda I 888/20 juin 1483 à l'âge de 80 ans

(Cf. Al-Sahāwī, al-Daw', vol. VIII, 205-207, n 539; 'Abd al-Bāsiṭ ibn Šāhīn alZāhirī, Nail, vol. VII, 349, 3240; ibn Iyās, Badā'i’, vol. II, 400)

\footnotetext{
${ }^{48}$-D'après le métier de son père. Al-Sahāwī, al-Ḍaw', vol. VIII, 205, n 539; 'Abd al-Bāsiț ibn Šāhīn alZāhirī, Nail, vol. VII, 349, n³240.
} 


\section{0- 'Alī ibn Aḥmad, ‘Alā' al-Dīn, ibn al-Ṣābūnī;}

Nommé en șafar 867/novembre 1462

Révoqué à une date indeterminée

Mort en muharram 873/août 1468

(Cf. al-Sahāwī, al-Daw', vol. V, 184-185, n 630; ibn Iyās, Badā 'í, vol. II, 400)

\section{1- Qānim ${ }^{49}$ min Șafar Hुuğā al-Mu'yyadī;}

Né en 791/1389

Nommé en ramaḍān 869/avril 1465

Révoqué à une date indeterminée

Mort en 10 șafar 871/21 septembre 1466 à l'âge de 80 ans

(Cf. 'Abd al-Bāsit ibn Šāhīn al-Zāhirī, Nail, vol. VI, 215, 250, n 2663; ibn Iyās, Badā' 'í, vol. II, 442-443; Hiba Yūsuf, « Le chef de la ronde », JAAUTH, vol. VIII/2, 95, $\left.\mathrm{n}^{\circ} 69\right)$

\section{2- 'Abd al-Bāsit ibn Yaḥīya, Šarf al-Dīn, ibn al- 'Alam ibn al-Baqarī;}

Nommé en muharram 873/août 1468

Révoqué en ğumāda II 874/décembre 1469

Mort en rabī' II 893/mars 1488

(Cf. Al-Ṣaīrafī, Inbā' al-haṣr bì anbā' al-'aṣr, réalisé par Hasan Habašì, Le Caire, 2002, 157-158; al-Sahāwī, al-P̣aw', vol. IV, 31-32, n 97; ibn Iyās, Badā' 'í, vol. III, 42)

\section{3- Abū'l-Futūḥ al-Mnūfī;}

Nommé en ğumāda II 874/décembre 1469

Révoqué à une date indeterminée

Mort à une date indeterminée

(Al-Ṣaīrafī, Inbā' al-hașr, 157-158; 'Abd al-Bāsiṭ ibn Šāhīn al-Ẓāhirī, Nail, vol. VI, 407; ibn Iyās, Badā' 'í, vol. III, 42)

\section{4- Timrāz al-Šamsī;}

Nommé en șafar 901/novembre 1495

Arrêté en dū'l-qi da 901/juillet 1496

Assassiné en dūu'l-hịğğa 902/août 1497

(Cf. Ibn Iyās, Badā' 'i , vol. III, 317, 373, 374; Aḥmad 'Issa, al-Bimāristānāt, 130, nº 13)

\footnotetext{
49- Qānim signifie mon sang. J. Sauvaget «Noms», JA, vol. CCXXXVIII, 52, n 149.
} 


\section{5- Muḥammad ibn Abī Yazīd;}

Nommé en rabī̄ I 902/novembre 1496

Révoqué à une date indeterminée

Mort à une date indeterminée

(Cf. Ibn Iyās, Badā' 'i , vol. III, 341)

\section{6- Mu īn al-Dīn ibn Šams al-Dīn;}

Nommé en šawwāl 908/avril 1503

Révoqué en șafar 916/mai 1510 à cause de disgrâce du sultan

Mort dans la prison d'al-Maqšara en muḥarram 917/avril 1511

(Cf. Ibn Iyās, Badā' 'i , vol. IV, 50, 211; Gaston Wiet, Journal d'un bourgeois du

Caire, Paris, 1955, vol. I, 177; Aḥmad 'Issa, al-Bimāristānāt, 130, n 14)

\section{7- Mạ̣mūd, Ḥussām al-Dīn, ibn ÁAd al-Bar ibn al-Šụ̣na;}

Nommé en șafar 916/mai 1510

Assassiné en rabī̄ I 923/mars 1517 à Bahnasa

(Cf. Ibn Iyās, Badā' ’’, vol. V, 173; Gaston Wiet, journal, vol. I, 177)

Il découle de cette étude biographique que les intendants de l'hôpital Manșūrī fírent parler d'eux à peu près pendant deux siècles et demi (684-923/1285-1517), et qu'ils donnèrent une idée assez claire de la débâcle et de l'instabilité qu'avait subies ce poste. Nous déduisons que l'époque mamelouke a été témoin de la nomination de 88 intendants de l'hôpital Manșūrī. Néanmoins, ce chiffre ne correspond pas au nombre réel des intendants nommés à l'époque mamelouke. En fait, nous avons remarqué la répétition de certains noms, ce qui veut dire que certains intendants avaient occupé ce poste plusieurs fois.

À la lumière du tableau suivant, nous tenterons de recenser les noms répétés afin de connaître le nombre de fois où chaque fonctionnaire avait occupé le poste de l'intendance de l'hôpital Manșūrī. Par conséquent, nous parviendrons à relever l'effectif réel des intendants.

Tableau $\left(\mathbf{n}^{\circ} \mathbf{1}\right)$

Indiquant les noms des intendants ayant rempli le poste deux fois

\begin{tabular}{|c|c|c|c|}
\hline Série & $\begin{array}{l}\text { Ordre de } \\
\text { l'intendant }\end{array}$ & Nom de l'intendant & $\begin{array}{l}\text { Nombre de fois de } \\
\text { nomination }\end{array}$ \\
\hline 1 & 11,15 & $\begin{array}{l}\text { Yūsusuf ibn Abī Bakr b. Muhammad, Ḍīyā' al-Dīn, } \\
\text { al-S̄âmī, dit Ibn Hațīb Bait al-abār }\end{array}$ & 2 \\
\hline 2 & 12,14 & $\begin{array}{l}\text { Alī ibn Muḥammad b. al-Ațrūšs, 'Alā' al- Dīn, al- } \\
\text { Saqați }\end{array}$ & 2 \\
\hline 3 & 20,25 & $\begin{array}{l}\text { Ibrāhim ibn Muhammad b. Abī Bakr, Burhān al- } \\
\text { Dīn, al-Sa dì al-Ahnā'si }\end{array}$ & 2 \\
\hline 4 & 26,28 & $\begin{array}{l}\text { Sākír ibn Ibrāhīm, Karīm al-Dīn, al-Qibțī, dit Ibn } \\
\text { al-Ğannām }\end{array}$ & 2 \\
\hline 5 & 43,47 & $\begin{array}{l}\text { 'Alī ibn Sa 'd al-Dīn ibn 'Abd Allah ibn } \\
\text { Muhammad, 'Alā' al-Dīn, al-Ṭablāwì }\end{array}$ & 2 \\
\hline
\end{tabular}


Selon le tableau précédent, cinq personnes auraient assumé chacun, deux fois, la responsabilité de l'intendance de l'hôpital Manșūrī. Ainsi, nous concluons que le nombre réel des intendants s'élève à quatre-vingt-trois intendants, dont trente-quatre appartenaient à l'époque des Mamelouks Baharites. Ils occupèrent ce poste trente-huit fois au cours de 101 ans, c'est-à-dire, en moyenne, deux ans et demi par intendant. Pourtant, certains intendants demeurèrent plus longtemps; marquant ainsi leur pouvoir et leur stabilité tels que Karīm al-Dīn 'Abd al-Karīm ibn Hibat Allah al-Sadīd ( $\left.\mathrm{n}^{\circ} 4\right)$ qui y demeura 13 ans, 'Alam al-Dīn Sanğar al-Ğāwlī (nº 9) qui y demeura 9 ans, et Mankalī Bug̣ā al-Šamsī ( $\left.n^{\circ} 22\right)$ qui y demeura 5 ans. Nous pouvons déduire également que quarante-neuf intendants, appartenant à l'époque circassienne, occupèrent l'intendace de l'hôpital Manșūrī cinquante fois durant 139 ans, c'est-àdire, une moyenne de trois ans par intendant. Néanmoins, certains trésoriers demeurèrent dans ce poste de longues périodes, tels que Ibn al-Ašqar $\left(\mathrm{n}^{\circ} 73\right), \mathrm{Mu}$ 'inn al-Dīn Šams al-Dīn ( $\left.n^{\circ} 86\right)$ et Ibn al-Šuhna ( $\left.n^{\circ} 87\right)$ qui y restèrent plus que 7 ans; tandis que Baibars al-Dawādār ( $\left.{ }^{\circ} 49\right)$ y demeura 6 ans.

D'autre part, ce poste avait connu des périodes de nomination très courtes au temps des Mamelouks Baharites. On remarque que deux intendants avaient occupé cette fonction moins d'une seule année $\left(\mathrm{n}^{\circ \mathrm{s}} 29,31\right)$. Il arriva même que cinq intendants $\left(\mathrm{n}^{\text {os }}\right.$ $27,28,31,32$ et 34 ) occupèrent les charges de ce poste moins de trois mois; alors qu'un intendant n'assuma guère cette fonction qu'une vingtaine de jours comme Karīm al-Dīn ibn al-Ġannām ( $\left.{ }^{\circ} 26\right)$, tandis que 'Izz al-Dīn Inabak al-Badrī $\left(n^{\circ} 33\right)$ ne prit en charge l'intendance de l'hôpital Manșūrī qu'une semaine à peine. Il arrivait même qu'un intendant comme Baraka al-Yalbugāāwi (n $\left.{ }^{\circ} 37\right)$ n'occupa les charges de ce poste qu'un seul jour et mandatait Ğamāl al-Dīn Maḥmūd al- Ağamī (nº 38) à sa place.

Quant à la dynastie circassienne, cette dégradation devint plus sensible durant la seconde dynastie qui avait connu la nomination de 50 intendants dont neuf occupèrent ce poste moins de deux ans ( $\mathrm{n}^{\text {os }} 47-48,50,64-66,68,70$ et 82 ).

La seconde dynastie mamelouke fut également témoin de la nomination des intendants qui ont occupé ce métier pour une seule année comme fut le cas d'Ibn alMuhalața $\left(n^{\circ} 78\right)$, tandis que Timrāz al-Šamsī $\left(n^{\circ} 84\right)$ y a été pour dix mois seulement. Entre autres, trois intendants ont perduré moins de six mois ( $\mathrm{n}^{\text {os }} 42,44$ et 63). Il arrivait même que six intendants ( ${ }^{\text {os }} 27-28,31-32,34$ et 69) occupèrent les charges de ce poste moins de trois mois, Ğānībak al-Ṣūfī ( $n^{\circ}$ 61) deux mois et finalement Quradamurdāš al-Yalbuğāwī ( $\left.\mathrm{n}^{\circ} 40\right)$ un seul mois.

On remarque également que la fin de la première dynatie des Mamelouks fut témoin du renforcement du pouvoir des intendants de l'hôpital Manșūrī qui avaient mandaté trois fois des personnes pour assumer les charges de ce poste. Notons, en cette occurrence, Mankalī Buġā al-Šamsī ( $\left.n^{\circ} 22\right)$ qui avait mandaté al- 'Ibțin̄̄ (n² 23); Ulğāy al-Yūsufī ( $\left.n^{\circ} 24\right)$ qui avait confié le poste à Ibrāhīm al-Ihnā'̄̄ (n² 25) et Barka alYalbugāāī (n³7) qui l'avait délégué à Ğamāl al-Dīn Maḥmūd al-'Ağamī (n 38). Ce phémonène fut également trois fois distingué sous la dynastie circassienne: Tamurtāš al-Muḥammadī ( $\left.n^{\circ} 53\right)$ avait mandaté Șalāḥ al-Dīn ibn Badr al-Dīn ( $\left.n^{\circ} 54\right)$ et Zaīn al- 
Dīn Muḥammad al-Daimairī ( $n^{\circ}$ 55); tandis que Ğānībak al-Ṣūfī (n 61) avait désigné al-Badraši (n 62).

Tableau ( $\mathbf{n}^{\circ}$ 2)

Représente une comparaison entre les intendants de l'hôpital Manșūrī sous la dynastie baharite et ceux de la dynastie circassienne

\begin{tabular}{|l|c|c|}
\hline & $\begin{array}{c}\text { La dynastie } \\
\text { baharite }\end{array}$ & $\begin{array}{c}\text { La dynastie } \\
\text { circassienne }\end{array}$ \\
\hline Nombre de nomination & 38 & 50 \\
\hline Nombre des titulaires & 34 & 49 \\
\hline La plus longue durée d'occupation & 13 ans & 7 ans \\
\hline La plus courte durée d'occupation & Un seul jour & Un seul mois \\
\hline Nombre d'intendants nommés deux fois & 4 & 1 \\
\hline Nombre d'intendants mandatés & 3 & 3 \\
\hline
\end{tabular}

Il arrivait que le sultan mit, deux fois, la main sur cette charge: la première fois remonte au temps du sultan al-Manșūr Qalāwūn après la fondation de l'hôpital Manșūrī en 684/1285 ${ }^{50}$; tandis que la seconde date du règne du sultan al-Ašraf Barsbāy le 13 rabī‘ II 837/27 novembre 1433 après la destitution de Sūdūn min 'Abd al-Raḥman ( $\left.{ }^{\circ} 68\right)$. Cette conjoncture provoqua la réprobation d'ibn Tağrībirdī qu'il considérait comme un précédent; car on avait l'habitude de confier l'intendance de l'hôpital Manșūrī au grand émir ${ }^{51}$.

Parmi les 88 biographies retenues par les osurces mameloukes: trente-neuf intendants furent choisis parmi les gens d'épée et ils ont réussi d'occuper ce poste quarante fois $\left(\mathrm{n}^{\text {os }} 5,9-10,13,16-19,22,24,29-35,37,40-44,47-51,53,56,59,61,63-68,70\right.$ et 84). Tandis que cinq intendants furent choisis parmi les civils et ils ont réussi d'occuper cette fonction six fois $\left(\mathrm{n}^{\circ \mathrm{s}} 4,26,28,73,75\right.$ et 86). Treize intendants furent choisis parmi les savants $\left(\mathrm{n}^{\circ \mathrm{s}} 3,23,39,46,62,71,74,76-80\right.$ et 82 ) et un seul était un témoin $\left(\mathrm{n}^{\circ} 60\right)$

D'ailleurs, si l'on parcourt les recueils de notices biographiques, on s'aperçoit que onze intendants furent choisis parmi les juges. Aussi, est-il arrivé que les charges de cette fonction furent confiées aux six muḥtasibs du Caire qui auraient occupé ce poste neuf fois $\left(\mathrm{n}^{\text {os }} 11-12,14-15,20,25,38,55\right.$ et 72/b). À en croire Abū'l-Futūh al-Mnūfĩ $\left(n^{\circ} 84\right)$ fut le seul scribe parmi les intendants de l'hôpital Manșūrī au temps des Mamelouks.

Citons enfin un fait significatif qui entraîna la dégradation de l'intendance de l'hôpital Manșūrī que l'on considérait comme une fonction essentiellement religieuse. Le 20 rağab 775/5 janvier 1374, le sultan al-Ašraf Ša 'bān y fit nommer, pour la première fois, un marchand d'épices $(k \bar{a} r i m i)^{52}\left(n^{\circ} 27\right)$. Il en fut de même pour un autre marchand de la dynastie circassienne $\left(n^{\circ} 81\right)$.

\footnotetext{
50- Al-Qalqašandī, Șubh, vol. III, 370.

51- Ibn Tağrībirdī, al-Nuğūm, vol. XV, 36; al-Șaīrafī, Nuzhat al-nufūs, vol. III, 227, nº 3.

52. Ce terme s'applique aux commerçants musulmans de toute nationalité, qui pratiquaient le commerce entre les Indes et l'Égypte et ils seraient ainsi des marchands de denrées étrangères.
} 
Il arrivait même que ce poste fut confié aux eunuques ( $\mathrm{n}^{\circ \mathrm{s}} 1$ et 69 ); ce qui laisse croire que l'objectif de certains sultans mamelouks était de recruter ces derniers, parce qu'ils n'aspiraient pas à transmettre un grand héritage à leurs successeurs.

Malgré leur variété, les sources mameloukes omettent de signaler les biographies de quatre intendants de l'hôpital Manșūrī ( $\mathrm{n}^{\circ}$ s 36, 45, 54 et 85).

Puisque c'était un poste religieux, on trouve que ces intendants étaient tous des musulmans sauf deux seulement d'origine copte, convertis à 1'Islam: Karīm al-Dīn 'Abd al-Karīm ibn Hibat Allah al-Sadīd (n 4$)$ ainsi que Karīm al-Dīn Šākir al-Qibṭī, dit Ibn al-Ġannām ( $\left.n^{\circ s} 26,28\right)$. De même, un seul intendant était d'origine juive, dont le grand-père s'est converti à l'islam: Fatḥ. Allah ibn Musta 'ṣim ibn Nafîs (n $\left.{ }^{\circ} 56\right)$.

En ce qui concerne l'autorité et la position politique dont avaient joui certains intendants, ce poste religieux permettait pafois à ses titulaires de devenir les maîtres absolus du pays comme Ibn al-Ṭablāwī $\left(n^{\circ s} 43,47\right)^{53}$, de tenir les rênes du pouvoir, d'avoir la parole tranchante comme Baibars al-Dawādār $\left(n^{\circ} 49\right)^{54}$ et même d'atteindre une position éminente tel que Țarābāy al-Ẓāhirī $\left(n^{\circ} 63\right)^{55}$ ainsi que Mu ${ }^{\circ} \bar{n}$ al-Dīn ibn Šams al-Dīn $\left(n^{\circ} 86\right)^{56}$. Sur le plan politique, ce poste avaient permis à certains de ses titulaires d'accéder aux postes les plus élevés dans la hiérarchie mamelouke.

Tableau $\left(\mathbf{n}^{\circ} \mathbf{3}\right)$

Indiquant les noms des intendants ayant obtenu le poste du vice-sultan

\begin{tabular}{|c|c|}
\hline Le nom & Date de nomination comme vice-sultan \\
\hline Aqtumur 'Abd al-Ġanī (n $\left.{ }^{\circ} 18\right)$ & rabī' II 775/septembre 1373 \\
\hline Qaštamur al-Manșūrī (nº 19) & 9 ğumāda I 762/18 mars 1360 \\
\hline Mankalī Bug̣ā al-Šamsī (nº 22) & 19 șafar $769 / 16$ octobre 1372 \\
\hline Tamurbāy al-Tamurtāšì (nº 35) & $780 / 1378$ \\
\hline Tağrībirdī al-Kamušbgāāwī (nْ 51) & $813 / 1410$ \\
\hline Țarābāy al-Ẓāhirī (nº 63) & ğumāda II 831/avril 1428 \\
\hline Ğarqațlū al-Ẓāhirī Barqūq (nº 67) & $835 / 1432$ \\
\hline Iynāl al-Ğakamī (nº 70) & rabīí I 839 \\
\hline
\end{tabular}

\section{Tableau $\left(n^{\circ} 4\right)$}

Indiquant les noms des intendants occupant le poste du chef de la ronde des rondes

\begin{tabular}{|l|l|}
\hline Nom & $\begin{array}{l}\text { Date de nomination comme chef de la } \\
\text { ronde des rondes }\end{array}$ \\
\hline Tamurbāy al-Tamurtāšs̄ $\left(\mathrm{n}^{\circ}\right.$ 35) & 5 ğumāda I 779/9 septembre 1377 \\
\hline Baraka al-Ğūbāni $\left(\mathrm{n}^{\circ}\right.$ 37) & rabī̄ II 780/juillet 1378 $^{\circ}$ \\
\hline
\end{tabular}

L'ensemble des biographies prouve que les intendants de l'hôpital Manșūrī occupaient une place prépondérante auprès des sultans mamelouks ainsi que dans la

Gaston Wiet, "Les marchands d'épices sous les sultans Mamlūks », Cahier d’Histoire Égyptienne, vol. VII, 1955, 87.

53. Al-Sahāwīi, al-Ḍaw', vol. V, 252-253, n 846; Wağīz, vol. I, 359, nº 800.

54- Ibn Iyās, Badā'i', vol. I/2, 737.

55. Ibn Iyās, Badā'i', vol. II, 79.

56- Ibn Iyās, Badā'i', vol. II, 79; vol. V, 50. 
société. Les sources mameloukes foisonnent en indices évidents et en évènements certains montrant les rapports étroits liant les sultans aux intendants et leurs positions sociales. Le 3 ramaḍān 745/14 janvier 1345, le sultan al-Nāșir Muhammad ibn Qalāwūn avait participé aux toilettes funèbres puis aux obsèques de Sanğar al-Ğāwlī $\left(n^{\circ} 9\right)^{57}$. Le sultan al-Ašraf Barsbāy quant à lui, assissta aux obsèques de l'émir Quğuq al-' '̇sāwī ( ${ }^{\circ}$ 65) qui eurent lieu à l'oratoire al-Mū'mnīis ${ }^{58}$, au pied de la citadelle en 829/1426 59 . Les historiens mamelouks racontent également que le même sultan, le calife 'abbasside al-Mu'tadid billah III Abū'l-Fath ainsi que les émirs et les notables avaient assisté aux obsèques de l'émir Yašbak al-Sāqī al-'A 'rağ (nº 66) à l'oratoire al-Mū'mn̄̄ le 3 ğumāda I 831/19 février $1428^{60}$. Par ailleurs, ces historiens étaient d'accord sur la participation du sultan al-Z̄āhir Ğaqmaq, des émirs et des notables de l'État aux obsèques de l'eunuque Ğawhar al-Qunqubā'ī al-Hāāindār (n ${ }^{\circ}$ 69) qui eurent lieu lors de sa mort au cours de ša bān 844/décembre $1440^{61}$.

Rappellons que le peuple avait regretté la mort de certains intendants comme Muhammad ibn Badr al-Dīn al-Dīn al-Damirī ( $n^{\circ}$ 72/a) ainsi que Muhammad ibn Badīr al- 'Abbāssī ( $\left.n^{\circ} 72 / b\right)$ qui était son beau-frère et son partenaire dans l'intendance de l'hôpital Manșūrī, grâce à leur bonne réputation ${ }^{62}$. On raconte aussi que les funérailles du marchand Qānim al-Mu'ayyadī ( $\left.\mathrm{n}^{\circ} 81\right)$ étaient solennellles car il était poli, courageux et sage ${ }^{63}$.

Les historiens mamelouks racontent également que la guérison de Karīm al-Dīn 'Abd al-Karīm ibn Hibat Allah al-Sadīd ( $\left.{ }^{\circ} 4\right)$ était fêtée avec beaucoup d'apparat, on décora la ville à cette occasion ${ }^{64}$.

Dans le cadre des relations sociales, il est à noter qu'il y avait des liens de parenté entre sept intendants et six sultans comme Badr al-Dīn Ğankalī al-Bābā (nº 10) qui avait marié sa fille à Ibrāhīm, fils du sultan al-Nāṣir Muḥammad ibn Qalāwūn ${ }^{65}$ et Arg̀ūn al-Nāșirī (n $\left.{ }^{\circ} 13\right)$ qui était le beau-père du sultan al-Malik al-Ṣālih Șālih (752$755 / 1351-1354)^{66}$. De même, Mankalī Bug̣ā al-Šamsī ( $\left.n^{\circ} 22\right)$ était le beau-frère du

\footnotetext{
57. Al-Șafadī, A'yān, vol. II, 469, nº 738.

58. I'oratoire al-Mū'mnī se trouve dans la rue d'al-Sayida 'Ā'iša dans la région d'al-Halīfa. II fut fondé par l'émir Baktumur al-Mu'mnī qui était un émir écuyer (amīr ahūr) du sultan al-Ašraf Ša'bān (764778/1363-1377). Il était l'oratoire officiel durant la période mamelouke. Muḥammad Ḥamza Ismāî̄l alḤaddād, "Muṣalla al-Mu'mnī bī'l-Qāhira », Dirāsāt wa buḥūt fíl ḥaḍāra al-islāmīya, Le Caire, 2000, vol. I, 437-448.

59. Al-Ṣaīrafi, Nuzhat al-nufūs, vol. III, 111-112, n 646.

60 - Al-Șaīrafi, Nuzhat al-nufūs, vol. III, 140, nº61.

61 - Ibn Tagriibirdī, al-Manhal, vol. V, 38-42, n 872.

62 - al-Saḩāwī, al-Tibr, vol. I, 149, 151.

63. Ibn lyās, Badā'i', vol. II, 443.

64- Al-Dֵahabī, al-'Ibar, vol. IV, 71; al-Kutbī, Fawāt, vol. II, 382; al-Ṣafadī, al-Wāfī, vol. XIX, 66-70, nº 7218

65. Ibn Tagrībirdī, al-Manhal, vol. V, 22-25, n 864.

66. Al-Maqrīzī, al-Sulūk, vol. IV, 24; Ibn Ḥağar al-'Asqalānī, al-Durar, vol. I, 353, n 875; Ibn Taġrībirdī, al-Dalīl, vol. I, 195.
} 
sultan al-Ašraf Ša 'bān ${ }^{67}$ (764-778/1363-1377), tandis qu’Ulğāy al-Yūsufī (n 24) était le beau-père du même $\operatorname{sultan}^{68}$, Baibars al-Dawādār ( $\left.{ }^{\circ}{ }^{49}\right)$ qui était le neveu du sultan al-Z̄āhir Barqūq (784-791/1382-1389) (792-801/1390-1399) ${ }^{69}$. Notons également que Saīf al-Dīn al-Ṭanbug̣ā al-Qirmšī ( $n^{\circ}$ 59) était le beau-fils du sultan alMalik al-Mu'ayyad Šaih (815-824/1412-1421) ${ }^{70}$, et Timrāz al-Šamsī (nº 84), le neveu du sultan al-Ašraf Qāitbāy (872-901/1468-1496) ${ }^{71}$. Nous pouvons aussi constater les liens de parenté entre certains intendants comme Țaštamur al-Laffāf $\left(n^{\circ} 31\right)$ le beaufils de son successeur Qarațāy al-Ašrafī $\left(n^{\circ} 32\right)^{72}$, ainsi que Zain al-Dīn Muhammad al-Daimairī ( $n^{\circ}$ 72/a) le beau-frère de Badr al-Dīn Muḥammad al- Abbāssī ( ${ }^{\circ}$ $72 / \mathrm{b})^{73}$.

Il faut également souligner que certains intendants réussirent à garder le poste dans leur famille comme Aqūš ibn 'Abd Allah al-Ašrafī (n 5) et 'Alā' al-Dīn 'Alī ibn alQalānsī ( $\left.{ }^{\circ} 6\right)$ qui étaient des frères, Faȟr al-Dīn 'Uțmān ibn Mușțafa ibn Ibrāhīm alMārdin̄̄ $\left(n^{\circ} 7\right)$ était le père de Aḥmad ibn Faḩr al-Dīn 'Uțmān al-Mārdin̄̄ (n $\left.{ }^{\circ} 8\right)$. De même pour Šaraf al-Dīn 'Uțman ibn Nūḥ ( $\left.{ }^{\circ} 39\right)$ qui était le père d'Ibn al-Ašqar ( ${ }^{\circ}$ $73)^{74}$. Siganlons aussi Šams al-Dīn Muḥammad al-Daimairī ( $\mathrm{n}^{\circ}$ 52) le père de Zaīn alDīn Muḥammad al-Daimairī ( $n^{\circ}$ 55) et le grand-père de Badr al-Dīn Muhammad alDamirī (n' $72 / a)^{75}$.

Il faut surtout reconnaître à certains intendants leur pitié et leur bonne conduite $\left(\mathrm{n}^{\circ} \mathrm{s} 3\right.$ 4, 20, 25, 29, 52, 55, 58, 63, 65-66, 69, 72/a, 77 et 84); à d'autres étaient leurs œuvres charitables ainsi que la distribution des aumônes aux pauvres ( ${ }^{\circ}{ }^{\text {s }} 10,13,44$ et 84). Karim al-Din ibn Hibat Allah $\left(n^{\circ} 4\right)$ était aussi connu par ses dons aux savants et pour les rembourssements des dettes des prisonniers ${ }^{76}$.

On rappelle également l'émir Mankalī Bug̣ā ( $\left.n^{\circ} 22\right)$ qui jouissait d'une réputation éprouvée de piété et de droiture et qui était un grand savant, poète, calligraphe, et même soufi ${ }^{77}$. À en croire Taqī al-Dīn Yahīya al-Karmān̄̄, ( ${ }^{\circ}$ 58) était un grand savant, poète, calligraphe et même soufi ${ }^{78}$.

\footnotetext{
67- Ibn Ḥağar al-'Asqalānī, al-Durar, vol. IV, 367, n 998; Ibn Taġrībirdī, al-Dalīl, vol. II, 744, n² 2542; alSahāwī, Wağīz, vol. I, 196, nº09.

68_ Ibn Hağar al-'Asqalānī, al-Durar al-kāmina, vol. I, 231, 433; Inbā', vol. I, 56-58, 64, $\mathrm{n}^{\circ} 9$; Ibn Tağrībirdī, al-Nuğūm, vol. XI, 57-58; al-Manhal, vol. III, 42, nº527; al-Dalīl, vol. I, 148, $\mathrm{n}^{\circ}$ 526; alSaḩāwī, Wağìz, vol. I, 197-198, nº 411.

69. Ibn Ḥağar al-'Asqalānī, Inbā', vol. II, 322, 323, 405, nº 5; Ibn Tağrībirdī, al-Manhal, vol. III, 481-483, $\mathrm{n}^{\circ} 726$; al-Dalīl, vol. I, 205-206, $\mathrm{n}^{\circ} 724$.

70. Ibn Tagrībirdī, al-Manhal, vol. III, 481-483, n 726; al-Dalīl, vol. I, 205 206, n 724.

Al-Șairafĩ avait indiqué qu'il était le cousin du sultan al-Ẓāhir Barqūq. Nuzhat al-nufūs, vol. II, 45.

71- Ibn lyās, Badā'i', vol. III, 374.

72- Ibn lyās, Badā'i', vol. I/2, 201.

73 - Al-Sahāwī, al-Tibr, vol. I, 151.

74 - Ibn Tagrīibirdī, al-Dalīl, vol. I, 439, nº 1517.

75. Al-Sahāwī, al-Tibr, vol. I, 151.

76 - Al-Šawkānī, al-Badr al-țāli', vol. I, 372-374, n 249.

77- Ibn Ḥağar al-'Asqalānī, al-Durar al-kāmina, vol. IV, 367, n 998; Inbä', vol. I, 54-55, $\mathrm{n}^{\circ}$ 45; Ibn Taġrībirdī, al-Dalīl, vol. II, 744-745, n²542; al-Sahāwī, Wağīz, vol. I, 196, n 409.

78. Ibn Ḥağar al-'Asqalānī, al-Durar al-kāmina, vol. IV, 367, n 998; Inbā', vol. I, 54-55, $\mathrm{n}^{\circ} 45$; Ibn Taġrībirdī, al-Dalīl, vol. II, 744-745, n²542; al-Sahāwī, Wağīz, vol. I, 196, n 409.
} 
Dans le cadre des soins accordés par certains intendants de l'hôpital Manșūrī, les sources mameloukes signalent que l'émir Ğamāl al-Dīn Aqūš (n 5) avait annexé une salle à l'hôpital Manșūrī en 726/1326 et qu'il avait également taillé les parois de l'hôpital ainsi que la coupole bâtis en pierre à un point qu'elles semblèrent être nouvelles. Il fixa aussi une tente dont la longueuer atteignit 100 coudées afin de protéger les personnes assises contre la chaleur. Il avait supprimé l'abreuvoir situé à côté de la porte de l'hôpital à cause de sa mauvaise odeur et avait construit à sa place une fontaine publique $(S a b \bar{l} l)^{79}$ pour que les gens puissent boire ${ }^{80}$. Al-Maqrīzī ajoute qu'Il avait effectué ces travaux à ses frais sans avoir recours aux biens morts ${ }^{81}$. Notons aussi que l'émir Saīf al-Dīn Arg̀ūn al- Alā'̄i (n $\left.{ }^{\circ} 13\right)$ avait fondé une fontaine publique à côté de la porte de l'hôpital et une école primaire $(K u t a \bar{b})$ pour la lecture du Coran et il consacra un waqf en l'honneur de ces deux bâtiments ${ }^{82}$.

D'après la liste des intendants, on peut conclure que vingt intendants furent assassinés ( ${ }^{\circ \mathrm{os}} 4,13,19,30,32-33,37,40,43,48-50,53,56,59,61,64,70,84$ et 87), tandis que quatre sont morts de la peste ( $\mathrm{n}^{\text {os }} 31,58,64$ et 76$)$, neuf morts en fonction $\left(\mathrm{n}^{\circ \mathrm{s}} 7,22,29,39,57,65-66,71\right.$ et 77$)$, deux dans la prison $\left(\mathrm{n}^{\circ} 5,17\right)$ et deux tués en combat $\left(\mathrm{n}^{\circ} 19,23\right)$. La liste représente aussi un seul intendant qui périt sous la torture dans la prison d'al-Maqšara $\left(n^{\circ} 86\right)$, un autre noyé $\left(n^{\circ} 24\right)$, un troisième décédé une grave maladie $\left(n^{\circ} 51\right)$ et un seul victime d'empoisonnement $\left(n^{\circ} 44\right)$. Le reste des intendants meurent après leur destitution.

Tableau $\left(\mathbf{n}^{\circ} \mathbf{5}\right)$

Indiquant les raisons de la mort des intendants de l'hôpital Manșūrī

\begin{tabular}{|l|c|c|}
\hline Mort & La dynastie bahararite & La dynastie circassienne \\
\hline Mort en fonction & 3 & 6 \\
\hline Assassiné & 6 & 11 \\
\hline Emprisonné & 2 & 1 \\
\hline Sous torture & - & 2 \\
\hline Étranglé & 1 & 1 \\
\hline Empoisonné & $\overline{1}$ & \\
\hline Noyé & 1 & 3 \\
\hline Attrapé l'épidémie de peste & $\overline{2}$ \\
\hline Après une grave maladie & 2 & \\
\hline En combat & & \\
\hline
\end{tabular}

79- Le mot sabil est dérivé du verbe arabe sabla qui signifie route ou bien bain mais ce mot désigne à l'époque mamelouke une construction charitable qui donne de l'eau à deux homme et animal. Șâlih Lam'ī, "The Carien Sabil », Muqarnas, vol. VI, 1989, 34-35.

80. Al- Șafadī, al-Wāfi, vol. IX, 195-197, n 1924; al-Maqrīzī, al-Sulūk, vol. III, 89; al-Muqqaffa, vol. II, 141-147, n' 816.

81- Al-Maqrīzī, al-Hițaț, vol. IV/ 2, 697; al-Sulūk, vol. III, 89; al-Muqqaffa, vol. II, 141-147, n 816; Ḥasan 'Abd al-Wahhāb, Tārīh al-masāğid al-ațārīya al-latī șala fiha farị̣at al-ğum'a haḍrat șāhib alğalāla al-malik al-ṣālị̣ Fārūq al-awal, Le Caire, 1964, vol. I, 122; Ahmad 'Abd al-Rāziq, al-'Imāra alislāmīya fí mișr mundu al-fath al-'arabì ḥata nihāyat al-'așr al-mamlūkī (21-923/641-1517), Le Caire, 2009, 244.

82 - Ibn Ḥağar al-'Asqalānī, al-Durar al-kāmina, vol. I, 353, nº 875. 
En effet, malgré leur abondance et leur variété, les sources mameloukes omettent de signaler la date de décès de cinq intendants ( $\mathrm{n}^{\text {os }} 36,45,54,83$ et 85$)$.

L'ensemble des biographies présente également des raisons assez importantes qui interprètent la dégradation qu'avait subie ce poste:

- Le cumul: il est évident que le cumul de plusieurs fonctions impacta négativement la performance de l'intendant de l'hôpital Manșūrī et participa par-là à semer les germes de la corruption dans le système administratif de l'État Mamelouk. Ce phénomène est devenu sous le règne des Mamelouks un fait normal ${ }^{83}$. Selon les sources mameloukes, certains intendants avaient cumulé l'intendance de l'hôpital Manșūrī avec d'autres fonctions religieuses, militaires et administratives. Parmi les fonctions religieuses, il y avait l'intendance du Trésor Public, cumulée par deux intendants avec celle de l'hôpital Manșūrī $\left(n^{\text {os }} 71,86\right)$. Ainsi, on a rencontré des intendants réunissant simultanément la fonction de l'intendance de l'hôpital Manșūrī avec celle de la hisba $\left(\mathrm{n}^{\text {os }} 11,15\right.$ et 38). Aussi, peut-on constater que Walī al-Dīn al-Safțī $\left(\mathrm{n}^{\circ} 74\right)$ avait associé cette charge aux fonctions d'intendant de kiswa, le Trésor Public et l'intendant d'al-Ğamālīya. Tandis que Abī al-Hair al-Naḥḥās (n ${ }^{\circ}$ 75) ainsi que son successeur Šaraf al-Dīn Mūsa al-Tatā'̄ $\left(n^{\circ} 76\right)$ avaient allié cette fonction avec quatre fonctions religieuses: l'intendance d'al-ğawāl $\bar{l}$, al-kiswa, du trésor public (Bait al-māl) et du couvent de $\mathrm{Sa}$ '̄ìd al- Su'adā'. Notons également Ibrāhīm al-Ihnā'̄̄ (n 20) qui avait cumulé l'intendance de l'hôpital Manșūrī avec celle de la juridiction.

Parmi les fonctions militaires que certains intendants avaient cumulé avec l'intendance de l'hôpital Manșūrī, la fonction de maréchal ( $\mathrm{n}^{\text {os }} 31,33,40-41,44,48$ 51, 53, 59, 61, 63-68 et 70). D'autres intendants avaient même cumulé leurs charges avec les fonctions de majordome ( $\left.\mathrm{n}^{\circ} 34\right)$, ou avec celle du chef de la ronde des rondes $\left(n^{\circ} 35\right)$. Signalons aussi 'Alā' al-Dīn al-Ṭablāwī ( $\left.n^{\circ} 43\right)$ qui était le préfet du Caire.

Quant aux fonctions administratives, un seul intendant $\left(\mathrm{n}^{\circ} 26\right)$ avait cumulé cette fonction avec trois autres fonctions administratives: le vizirat, l'intendance des maisons sultaniennes et la maison de texile (Dār al-Ṭirāz).

Toutefois, comment un seul homme pouvait-il assumer correctement plusieurs fonctions à la fois?

- La nomination des incompétents: la dégradation et l'instabilité de cette charge se faisaient encore sentir lorsqu'il s'agissait de la nomination des incompétents comme 'Alā' al-Dīn ibn al-Ațrūš $\left(n^{o s} 12,14\right)^{84}$. Il est arrivé que ce poste fut confié à une personne sans aucun savoir ni science comme Nūr al-Dīn al-Safțī $\left(n^{\circ} 60\right)^{85}$ et parfois, sans religion ou mode de vie connus de lui comme Saif al-Dīn Baībug̀ā al-

\footnotetext{
83. Aḥmad 'Abd al-Rāziq, al-Baḍll wa'l-barțala zaman salāțīn al-mamālīk, Le Caire, 1979; 7176; «La hisba ", AnIsl, vol. XIII, 126; « Le vizirat ", Anlsl, vol. XVI, 235.

84- Al-Maqrīzī, al-Sulūk, vol. IV, 134; Ḥayāt Nāṣir al-Ḥiğğ̄̄, " al-Bimāristān al-Manșūrī », AJH, vol. VIII/ 29, 27

85- al-Sahāwī, al-Daw', vol. VI, 58, nº 175.
} 
Muzaffarī ( $n^{\circ}$ 64) ou enfin à un des bâtards proches du sultan comme Abī al-Hair alNaḥhās $\left(n^{\circ} 75\right)^{86}$.

- La nomination des gens d'épée à la place des gens de loi, quand bien même que cette charge fut initialement considérée comme une fonction religieuse. Les gens d'épée représentaient la majorité des titulaires de ce poste. Il parait que les sultans mamelouks voulaient écarter par ce remplacement les religieux qui se montraient peu dignes de la charge, ou probablement ils voulaient s'assurer le contrôle de ce poste en désignant un de leurs officiers. Puis, cette fonction fut également occupée par deux marchands ( $n^{\text {os }} 27,81$ ) ainsi que par deux eunuques $\left(n^{\circ s} 1,69\right)$ qui ne cherchaient pas à s'enrichir car ils n'avaient pas des héritiers.

- Les relations personnelles: le piston avait joué un rôle majeur dans la nomination de certains intendants de l'hôpital Manșūrī ayant des bons rapports avec le sultan comme Barka al-Yalbuḡāwī ( $\left.n^{\circ} 37\right)$ qui était le compagnon du sultan al-Zāhir Barqūq ${ }^{87}$. Il en était de même pour Taqī al-Dīn yiḥīya al-Karmānī ( $\left.n^{\circ} 58\right)$ qui était sourd mais il fut nommé car il était très proche d'al-Mu'ayyad Šaih avant d'être proclamé sultan. On raconte qu'il avait accompagné ce dernier lorsqu'il fut nommé vice- sultan de Tripoli ${ }^{88}$ ou à un des racailles préférés du sultan comme Abī al-Hair al-Naḥhās $\left(n^{\circ} 75\right)^{89}$.

- Les dépositions brutales: elles sont aussi un fait significatif de la dégradation de l'intendance de l'hôpital Manșūrī au temps des Mamelouks. Nous remarquons aussi que la plupart de ces dépositions n'avaient pas des raisons à l'exception de deux cas, celui de Sūdūn min 'Abd al-Raḥman ( ${ }^{\circ}$ 68) déstitué à cause de sa faiblesse ${ }^{90}$ et celui de Mu īn al-Dīn ibn Šams al-Dīn ( $\left.n^{\circ} 86\right)$ disgrâcié par le sultan Qānșwah alĠawrî ${ }^{-11}$. Il arrivait même que six intendants ( ${ }^{\circ \mathrm{s}} 27-28,31-32,34$ et 69) occupèrent les charges de ce poste moins de trois mois. Rappellons aussi Ğānībak al-Ṣūfī (nº 61) qui n'occupa l'intendance de l'hôpital Manșūrī que pour deux mois; tandis que Qurādamurdāš al-Yalbugiāwī ( $\left.n^{\circ} 40\right)$ ne demeura dans cette fonction qu'un seul mois.

- La vénalité des charges: la débâcle et l'instabilité des intendants de l'hôpital Manșūrī se faisaient également sentir lorsqu'il s'agissait d'une vénalité des charges. Celle-ci favorisait la désignation des ignorants qui arrivèrent à occuper ce poste bien noble comme 'Alā' al-Dīn Alī al-Ṭablāwī ( $\left.n^{\text {os }} 43,47\right)^{92}$. Cependant, nous n'avons pas trouvé des renseignements fiables concernant les prix d'achat de cet emploi à l'époque mamelouke.

\footnotetext{
86- Ibn Tağrībirdī, al-Dalīl, vol. II, 828, n² 2785.

87. Ibn Tağrībirdī, al-Nuğūm, vol. XI, 204; al-Dalīl, vol. I, 189, nº60.

88. Al-Maqrīzī, al-Sulūk, vol. VII, 219; al-Șaīrafī, Nuzhat al-nufūs, vol. III, 210, nº 693.

89. Ibn Tagrībirdī, al-Dalīl, vol. II, 828, n²785.

90. Ibn Ḥağar al-'Asqalānī, Inbā', vol. III, 473, 481, 513; vol. IV, 81, n 15; Ibn Taġrībirdī, alNuğūm, vol. XV, 221; al- Manhal, vol. VI, 152-156, n 1144; al-Dalïl, vol. I, 332, n 114; alȘairafī, Nuzhat al-nufūs, vol. III, 233, 275.

91- Ibn Iyās, Badā'i', vol. IV, 50, 211; Gaston Wiet, Journal d'un bourgeois, vol. I, 177.

92- Ibn Taǵrībirdī, al-Manhal, vol. VIII, 93, nº 1600.
} 
Au regard de ces informations sur le déclin de ce poste à l'époque mamelouke, nous devons attirer l'attention sur les confiscations et les tortures que plusieurs intendants ont éprouvées. En effet, les sources mameloukes abondent en informations sur ce sujet. On signale le cas de Karīm al-Dīn ibn Hibat Allah al-Sadīd ( $\left.{ }^{\circ} 4\right)$ qui fut exilé, confisqué et finit par être étranglée ${ }^{93}$. On souligne aussi la confiscation d'Ibn alQalānsī (n $\left.{ }^{\circ} 6\right)^{94}$ ainsi que Ḍīyā' al-Dīn Yūsuf al-Šāmī $\left(n^{\circ s} 11,15\right)$ qui se fit arrêter en en ša'bān 747/novembre 1346. On le condamna par la suite à une promenade infamante juché, tout nu, sur un âne puis on le bastonna avant d'être exilé après sa confiscation $^{95}$. Nous constatons aussi que les femmes des intendants de l'hôpital Manșūrī étaient parfois les victimes de la politique de leurs époux. On souligne également que l'épouse de l'émir Inabak al-Badrī ( $\left.n^{\circ} 33\right)$ fut la première à être requisitionnée parmi les femmes des émirs ${ }^{96}$. Rappelons aussi que Alī al-Ṭablāwī (n ${ }^{\circ}$ 43, 47) fut torturé et confisqué ${ }^{97}$ ainsi que Fath Allah ibn Musta 'șim (n $\left.{ }^{\circ} 56\right)$ arrêté, confisqué et finalement étranglé par ordre du sultan al-Mu'ayyad Šaih ${ }^{98}$. On parle aussi de la confiscation importante et de de la torture atroce qui provoqua la mort de Mu'īn al-Dīn ibn Šams al-Dīn $\left(n^{\circ}\right.$ 86) en muḥarram 916/avril 1510. Les sources mameloukes nous apprennent qu'il mourut après un supplice effroyable dont une compression des talons, en plus de la saisie de ses biens. Personne ne regretta sa mort car il avait une réputation infamante ${ }^{99}$.

En fin de compte, il nous parait autant impératif qu'équitable de signaler les exemples isolés de quelques intendants qui surent sauvegarder leur honoabilité et leur respect. Parmi ces derniers, on peut mentionner Šams al-Dīn Aḥmad al- Surūğī (n 3) connu pour son comportement respectueux. Aussi pouvons-nous supposer que le titulaire jouissait parfois d'une réputation éprouvée de bonne conduite, de piété et de droiture, comme ce fut le cas de $\left(\mathrm{n}^{\circ \mathrm{s}} 20,25,52,55,63,65\right.$ et 66). Certains intendants avaient gagné une bonne réputation et une grande popularité grâce à leur sagesse, modestie, justice et intégrité ( $\mathrm{n}^{\text {os }} 6,22,29,59,69,72 / \mathrm{a}-\mathrm{b}, 77$ et 78). D'autres furent connus par la distribution des aumônes ainsi que les œuvres charitables de certains intendants ( $\mathrm{n}^{\circ \mathrm{s}} 10,13,59$ et 84$)$.

Nous ne pouvons pas, somme toute, passer sous silence les fortunes immenses de ces intendants comme Karīm al-Dīn ibn Hibat Allah al-Sadīd $\left(n^{\circ} 4\right)^{100}$ ainsi que Saif

\footnotetext{
93-Al-Šawkānī, al-Badr, vol. I, 372-374, n² 249; al-Ṣafadī, A'yān al-'așr, vol. III, 142, n 1030; Ibn Taǵribirdī, al-Dalīl, vol. I, 426, n 1469.

94- Al-Ṣafadī, al-Wāfī, vol. XXII, 88, n 84.

95 -Al-Maqrīzī, al-Sulūk, vol. IV, 237; Ḥayāt al-Ḥiğğ̄̄, "al-Bimāristān al-Manșūrī", AJH, vol. $\mathrm{VIII} / 29,28$. 
al-Dīn Arḡūn al-Nāṣirī ( $\left.n^{\circ} 13\right)$ connu par sa richesse soit des propriétés soit des fiefs $^{101}$.

\section{Conclusion}

Il resort de cette étude que la charge de l'intendance de l'hôpital Manșūrī compta parmi les majestueuses fonctions religieuse connues à l'époque mamelouke. Elle ne fut confié qu'à des notables musulmans respectés pour leur probité, car cette fonction porte un caractère religieux. Elle était jadis attribuée uniquement à des gens de loi. Par la suite, on y nomma les gens d'épée, des civils, des marchands et même des eunuques, ce qui prouve l'importance de cette fonction tant convoitée par tout le monde. Certains intendants avaient joui d'une haute position sociale auprès de certains sultans la preuve est la participation des sultans aux obsèques de quelquesuns. L'étude a également dévoilé la richesse et les fiefs qu'avaient possédés quelques titulaires.

Cette position avait cependant subi une décadence due à l'agencement de plusieurs facteurs parmi lesquels: le cumul, les dépositions brutales, les relations de parenté qui avaient lié certains intendants, le piston, le cumul, la vénalité et les relations personnelles. Malheureusement, ces facteurs avaient dominé tandis que les aptitudes et les compétences des personnes aspirant au poste étaient totalement méconnues. C'est ainsi que des ignorants et des non-qualifiés accédèrent à cette fonction si noble qu'est l'intendance de l'hôpital Manșūrī, à coup sûr, une fonction politique et militaire plus que religieuse et sociale

101_ Al-Ṣafadī, al-Wāfí, vol. VIII, 230, nº 1443. 


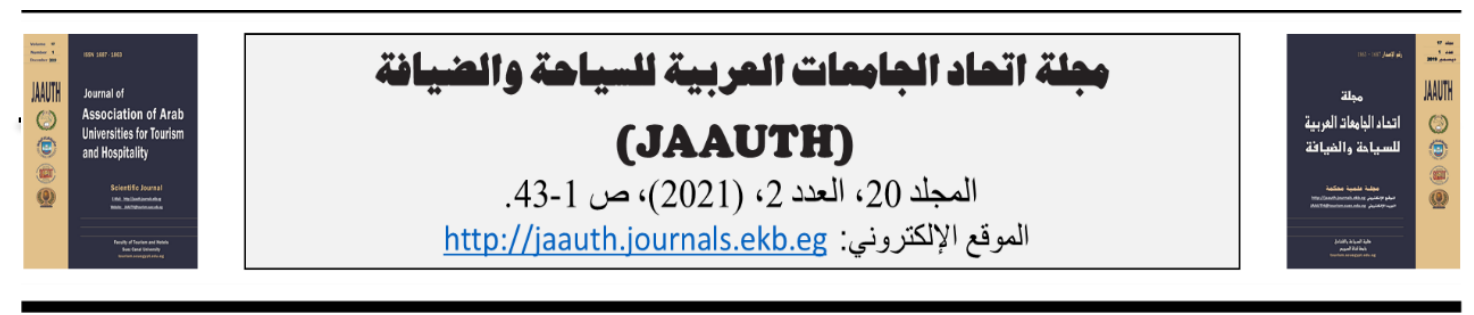

ثبت زمني باسماء نظار المارستان المنصوري زمن سلاطين المماليك

$$
\begin{aligned}
& \text { (10IV_IrAO/9rr_T1s) } \\
& \text { رانيا أسامة علي فكر }
\end{aligned}
$$

\begin{tabular}{|c|c|}
\hline & \\
\hline 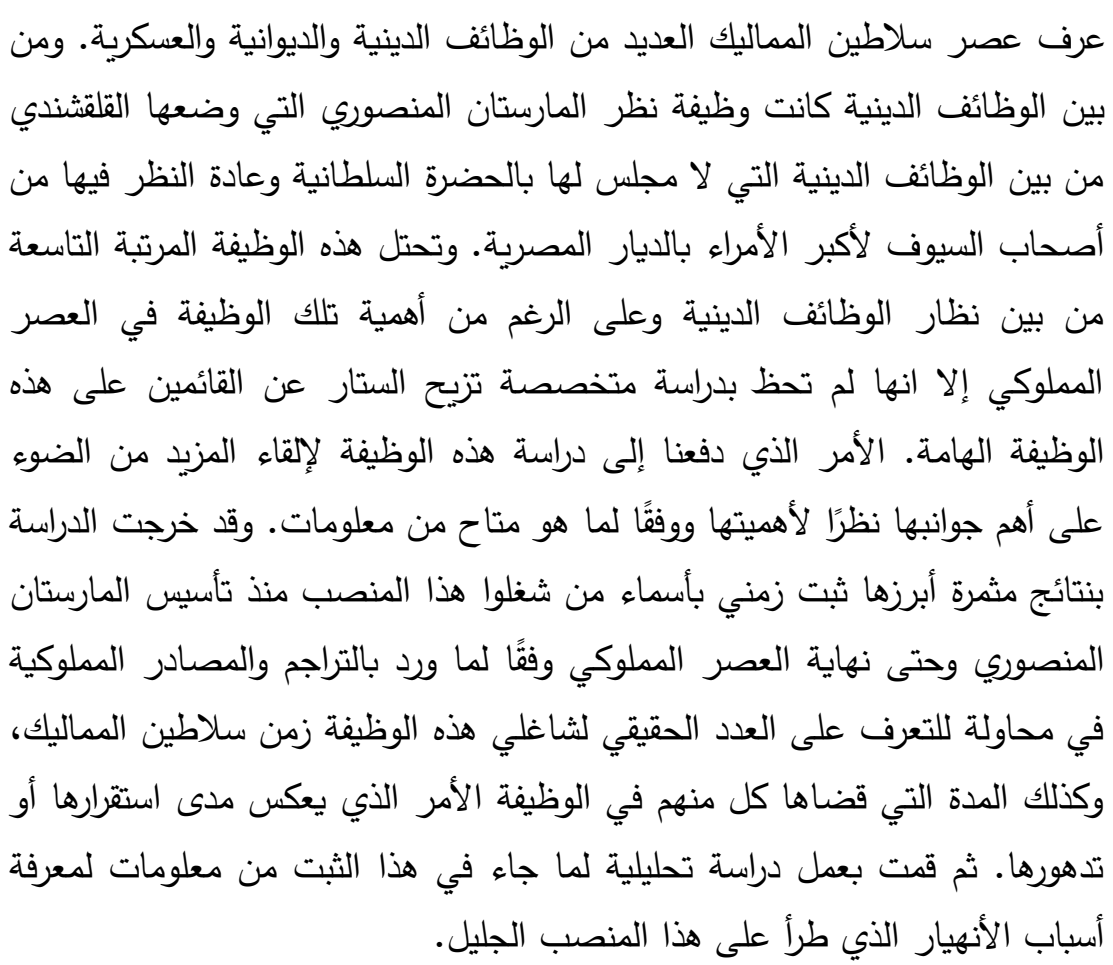 & الماظر البيمارستان المنصوري؛ (البيمارستان)؛ \\
\hline
\end{tabular}

قسم الإرشاد السياحي، كلية الآداب، جامعة عين شمس لمس 